\title{
Optogenetic Activation of Cajal-Retzius Cells Reveals Their Glutamatergic Output and a Novel Feedforward Circuit in the Developing Mouse Hippocampus
}

\author{
Giulia Quattrocolo and Gianmaria Maccaferri \\ Department of Physiology, Feinberg School of Medicine, Northwestern University, Chicago, Illinois 60611
}

\begin{abstract}
Cajal-Retzius cells orchestrate the development of cortical circuits by secreting the glycoprotein reelin. However, their computational functions are still unknown. In fact, the nature of their postsynaptic targets, major neurotransmitter released, as well as the class of postsynaptic receptors activated by their firing remain unclear. Here, we have addressed these questions by activating Cajal-Retzius cells optogenetically in mouse hippocampal slices. Light delivered to stratum lacunosum-moleculare triggered EPSCs both on local interneurons and on pyramidal cells. Responses recorded under voltage-clamp conditions had identical short latencies and similar amplitudes, but were kinetically different (i.e., faster in interneurons vs pyramidal cells). In both cases, responses were blocked by TTX, indicating that they were generated by action potential-dependent release. Responses in interneurons were rescued by the addition of 4-AP to TTX, and decreased when presynaptic firing in Cajal-Retzius cells was reduced by the chemokine CXCL12, indicating the existence of a direct Cajal-Retzius cellinterneuron monosynaptic connection. Although the combined application of 4-AP and TTX did not rescue responses in pyramidal cells, neither were they affected by the $\mathrm{GABA}_{\mathrm{A}}$ receptor blocker gabazine, which would be expected if they were polysynaptic. Both connections showed physiological and pharmacological properties indicating the involvement of AMPA- and NMDA-type glutamate receptors. The connectivity from presynaptic Cajal-Retzius cells to interneurons was strong enough to generate long-latency feedforward GABAergic input onto pyramidal cells. We propose that this newly defined Cajal-Retzius cell-dependent microcircuit may regulate synaptic plasticity and dendritic development in stratum lacunosum-moleculare, thus impacting the integrative properties of the developing hippocampus.
\end{abstract}

Key words: AMPA receptor; chemokine; GABAA receptor; glutamate; interneuron; NMDA receptor

\section{Introduction}

Despite having been described more than a century ago, CajalRetzius cells remain an enigmatic neuronal type (Soriano and Del Río, 2005). The discovery of their immunoreactivity to the allelic antigen missing in the reeler mouse (Ogawa et al., 1995), together with the identification of this gene as reelin (D'Arcangelo et al., 1995), led to the proposal that Cajal-Retzius cells are critical for the correct assembly of maturing cortical circuits (Frotscher, 1998). For these reasons, a large number of studies has focused on reelin-dependent roles of Cajal-Retzius cells, which operate at relatively slow time scales during development (Del Río et al., 1997; Borrell et al., 2007; Hammond et al., 2010; Franco et al.,

Received April 6, 2014; revised Aug. 12, 2014; accepted Aug. 13, 2014.

Author contributions: G.Q. and G.M. designed research; G.Q. and G.M. performed research; G.Q. and G.M. analyzed data; G.Q. and G.M. wrote the paper.

This work was supported by the National Institute of Neurological Disease and Stroke (Grant NS 064135 to G.M.). We thank Dr. Ulrich Müller (the Scripps Research Institute) and the MMRRC for generously providing us with the Wnt3a-IRES-Cre mice. We also thank Dr. Gabriella Sekerkova (Northwestern University) for help and advice involving the immunocytochemical experiments and for the generation of Figure 1 and part of Figure 12. In addition, we thank Dr. Maximiliano Nigro (Northwestern University) for help with the identification of entorhinal cortex neurons; Dr Marco Martina (Northwestern University) for comments on this manuscript; and Sun Kyong Lee for expert technical help.

Correspondence should be addressed to Gianmaria Maccaferri, Department of Physiology, Feinberg School of Medicine, 303 E. Chicago Avenue, Tarry Building, Room 5-707 M211, Chicago, IL 60611. E-mail: g-maccaferri@northwestern.edu.

DOI:10.1523/JNEUROSCI.1407-14.2014

Copyright $\odot 2014$ the authors $\quad 0270-6474 / 14 / 3413018-15 \$ 15.00 / 0$
2011; Gil-Sanz et al., 2013; for review, see also Tissir and Goffinet, 2003). In contrast, knowledge of their fast synaptic signaling is still relatively scarce. Yet, this is a critical issue, because computations performed by neurons within specific brain networks depend on the physiological properties of their input and output synapses (Shepherd and Koch, 1990).

We have recently begun to address these latter points for Cajal-Retzius cells of the hippocampus. Similarly to neocortical Cajal-Retzius cells (Kilb and Luhmann, 2001; Soda et al., 2003; Cosgrove and Maccaferri, 2012), we have also observed in the hippocampus that spontaneous synaptic input to these neurons is mostly, if not exclusively, due to $\mathrm{GABA}_{\mathrm{A}}$ receptor-mediated postsynaptic currents (Marchionni et al., 2010; Quattrocolo and Maccaferri, 2013). In addition, we have identified specific interneurons types, such as stratum lacunosum-moleculare neurogliaform cells (for review, see Capogna, 2011; Armstrong et al., 2012) and oriens lacunosum-moleculare (O-LM) interneurons (Maccaferri et al., 2000; Maccaferri, 2005), as presynaptic elements mediating either Cajal-Retzius cell excitation and firing or depolarization block and inhibition via $\mathrm{GABA}_{\mathrm{A}}$ receptormediated signaling (Quattrocolo and Maccaferri, 2013).

Thus, because of this cell type-specific input, Cajal-Retzius cell firing would be predicted to be modulated by hippocampal rhythmic states associated with activation of neurogliaform and O-LM interneurons (Klausberger et al., 2003; Fuentealba et al., 2010; Varga et al., 2012). 
However, it is difficult to expand these predictions into meaningful hypotheses because of the lack of knowledge both of the receptor mechanisms mediating their synaptic output and of their target-cell connectivity. In fact, contrasting results have suggested that Cajal-Retzius cells express either a GABAergic (Imamoto et al., 1994; Marín-Padilla, 1998; Pesold et al., 1998) or a glutamatergic phenotype (del Río et al., 1995; Hevner et al., 2003; Ina et al., 2007). Furthermore, their postsynaptic targets remain undetermined.

Here, we directly address these issues by taking advantage of optogenetic techniques. Our results indicate that Cajal-Retzius cells form excitatory connections onto interneurons and also affect pyramidal cells by activating postsynaptic AMPA- and NMDA-type glutamate receptors. Furthermore, we show that this network arrangement generates a powerful feedforward GABAergic input onto pyramidal cells.

We propose that synaptic signaling by this newly defined microcircuit contributes to the maturation and/or plasticity of temporoammonic synapses of the stratum lacunosum-moleculare network (Maccaferri, 2011), thus ultimately affecting hippocampal rate codes and their integrative functions (Ahmed and Metha, 2009).

\section{Materials and Methods}

Ethical approval. All animal procedures used in this study were in compliance with the guidelines provided by the Institutional Animal Care and Use Committee of Northwestern University and the National Institutes of Health.

Animals. The animals used in this study were generated by breeding

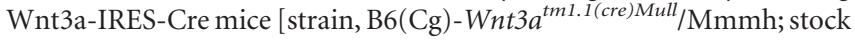
number, 031748-MU (RRID:IMSR_MMRRC:031748), henceforth referred to as Wnt3a-IRES-Cre; see Gil-Sanz et al., 2013] with a strain that conditionally expresses an improved channelrhodopsin-2(ChR2)/EYFP (enhanced yellow fluorescent protein) fusion protein [ChR2(H134R)EYFP] following Cre-mediated removal of the floxed STOP cassette [strain, B6;129S-Gt(ROSA)26Sor ${ }^{\text {tm } 32\left(C A G-C O P 4^{*} H 134 R / E Y F P\right) H z e} /$ J; stock number, 012569 (RRID:MGI_MGI:5013789), henceforth referred to as ChR2(H134R)-EYFP; Madisen et al., 2012]. Animals of either sex were used throughout this study.

Histological analysis, microscopy, and photography. Postnatal day 14 (P14) mice (five animals from five different litters) were used for immunocytochemical experiments. Animals were anesthetized by intraperitoneal injection of sodium pentobarbital $(60 \mathrm{mg} / \mathrm{kg}$ body weight $)$ and perfused with isotonic saline followed by $4 \%$ formaldehyde in $0.12 \mathrm{M}$ phosphate buffer ( $\mathrm{PB}), \mathrm{pH}$ 7.4. After perfusion, mice were maintained in situ for $1 \mathrm{~h}$, then brains were dissected and cryoprotected in $30 \%$ sucrose in PBS. Hippocampal sections were cut serially at $40 \mu \mathrm{m}$ on a freezingstage microtome. Immunocytochemical reactions for ChR2(H134R)EYFP mice were performed as follows. For bright-field microscopy, sections were incubated with the primary antibody rabbit anti-GFP [1: 3000; catalog \#G10362 (RRID:AB_10565179), Life Technologies], enhanced with a secondary biotynilated antibody (1:500; catalog \#RPN1004-2ML (RRID:AB_1062582), Life Technologies], and processed according to an avidin/biotin amplification protocol (Elite ABC Vectastain, Vector Laboratories). Bright-field images were acquired with a Spot RT CCD video camera (Diagnostic Instruments) mounted on a Nikon Eclipse E800 microscope. For immunofluorescence and confocal imaging, sections were incubated with the following mixture of primary antibodies: rabbit anti-GFP [1:3000; catalog \#G10362 (RRID:AB_10565179), Life Technologies]; and mouse antireelin [1:1000; catalog \#MAB5364 (RRID:AB_2179313), EMD Millipore]. Bound primary antibodies were visualized by secondary antibodies coupled to Alexa Fluor 488 [1:600; catalog \#A11034 (RRID: AB_10562715), Life Technologies] and Alexa Fluor 594 [catalog \#A11032 (RRID:AB_10562708), Life Technologies]. Laser-scanning confocal images were obtained with a Nikon PCM 2000 Confocal Microscope System, mounted on the Eclipse microscope.
Slice preparation. Acute hippocampal slices (400 $\mu \mathrm{m}$ thick) were prepared from young animals (P8-P18). Mice were deeply anesthetized with isoflurane and decapitated. The brain was removed and placed into a small container filled with chilled modified artificial CSF (ACSF; in mu) as follows: $130 \mathrm{NaCl}, 24 \mathrm{NaHCO}_{3}, 3.5 \mathrm{KCl}, 1.25 \mathrm{NaH}_{2} \mathrm{PO}_{4}, 1 \mathrm{CaCl}_{2}$, $2 \mathrm{MgCl}_{2}, 10$ glucose, saturated with $95 \% \mathrm{O}_{2}, 5 \% \mathrm{CO}_{2}$ at $\mathrm{pH}$ 7.4. Transverse sections were cut using a vibrating microtome (VT $1000 \mathrm{~S}$ or VT $1200 \mathrm{~S}$, Leica). Slices were then incubated at $34-35^{\circ} \mathrm{C}$ for at least $30 \mathrm{~min}$ and then stored at room temperature until use. A cut eliminating the CA3 region was made in some of the experiments. As no differences were noted with intact slices, this was not consistently performed, and results were pooled together.

Electrophysiological recordings. Slices were transferred to a direct microscope (either Scientifica or Olympus) with oblique illumination optics (Olympus) and an infrared camera system (VX-55, TILL Photonics). Cells were visualized using a $60 \times$ infrared water-immersion objective. Slices were superfused with preheated ACSF of the following composition (in mM): $130 \mathrm{NaCl}, 24 \mathrm{NaHCO}_{3}, 3.5 \mathrm{KCl}, 1.25 \mathrm{NaH}_{2} \mathrm{PO}_{4}, 2 \mathrm{CaCl}_{2}, 1$ $\mathrm{MgCl}_{2}, 10$ glucose, saturated with $95 \% \mathrm{O}_{2}, 5 \% \mathrm{CO}_{2}$ at $\mathrm{pH} 7.4$ and maintained at a constant temperature $\left(31-33^{\circ} \mathrm{C}\right)$ by a temperature controller (TC-324B, Warner Instruments).

Interneurons of stratum lacunosum-moleculare were selected according to their localization, preferably close to the fissure, as shown by Zsiros and Maccaferri (2005). Cajal-Retzius cells, cells were recognized by their location, typical tadpole shape, and EYFP fluorescence. Principal neurons of the entorhinal cortex from layers II and III were recorded both in the medial and lateral entorhinal cortex. Because results were not different, data were pooled together.

Recording pipettes were pulled from borosilicate glass capillaries (Prism FLG15, Dagan Corporation) and had a resistance of 3-5 M $\Omega$ when filled with the appropriate internal solution, as reported below. Recordings were performed using a Multiclamp 700 amplifier (Molecular Devices). The signals were filtered at $3 \mathrm{kHz}$ and digitized at $20 \mathrm{kHz}$ using a Digidata 1322A and the Clampex 9 program suite (Molecular Devices). Voltage-clamp recordings were performed at the holding potential indicated in the text, while cell-attached recordings were performed at a holding potential of $0 \mathrm{mV}$. Series resistances were monitored through the injection of a 5- to $10-\mathrm{mV}$-step in voltage clamp, but not corrected. The overall series resistance was estimated to be $22 \pm 1 \mathrm{M} \Omega$ ( $n=45$ cells).

Pipette solutions. The solution for voltage-clamp recordings from hippocampal Cajal-Retzius cells, interneurons, pyramidal cells, and entorhinal cortex neurons was as follows (in $\mathrm{mM}$ ): 125 Cs-methanesulfonate ( $\mathrm{KCl}$ for some experiments shown in Fig. 13), 0.3 GTP-Na, 4 ATP- $\mathrm{Mg}_{2}$, $16 \mathrm{KHCO}_{3}, 10 \mathrm{QX}-314 \mathrm{Cl}$ and $0.3-0.5 \%$ biocytin, equilibrated with $95 \%$ $\mathrm{O}_{2}, 5 \% \mathrm{CO}_{2}$ to $\mathrm{pH} 7.3$.

The solution for current-clamp recordings from interneurons was as follows (in mM): $125 \mathrm{~K}$-methylsulfate, $10 \mathrm{NaCl}, 0.3 \mathrm{GTP}-\mathrm{Na}, 4 \mathrm{ATP}-\mathrm{Mg}_{2}$, $16 \mathrm{KHCO}_{3}$ and $0.3-0.5 \%$ biocytin, equilibrated with $95 \% \mathrm{O}_{2}, 5 \% \mathrm{CO}_{2}$ to $\mathrm{pH} 7.3$.

The solution for current-clamp recordings from Cajal-Retzius cells was as follows (in mM): $105 \mathrm{~K}$-methylsulfate, $10 \mathrm{NaCl}, 20 \mathrm{KCl}, 0.3 \mathrm{GTP}$ $\mathrm{Na}, 4 \mathrm{ATP}-\mathrm{Mg}_{2}, 16 \mathrm{KHCO}_{3}$ and $0.3-0.5 \%$ biocytin, equilibrated with $95 \% \mathrm{O}_{2}, 5 \% \mathrm{CO}_{2}$ to $\mathrm{pH} 7.3$.

The solution for cell-attached recordings from Cajal-Retzius cells and entorhinal cortex neurons was as follows (in $\mathrm{mm}$ ): $130 \mathrm{NaCl}, 24$ $\mathrm{NaHCO}_{3}, 3.5 \mathrm{KCl}, 1.25 \mathrm{NaH}_{2} \mathrm{PO}_{4}, 2 \mathrm{CaCl}_{2}, 1 \mathrm{MgCl}_{2}, 10$ glucose, saturated with $95 \% \mathrm{O}_{2}, 5 \% \mathrm{CO}_{2}$ at $\mathrm{pH} 7.4$.

Optogenetic stimulation of neurons. Blue light was transmitted to the slice from a collimated LED (Prizmatix) attached to the epifluorescence port of a direct microscope. Brief (1-5 ms) light flashes were directed to stratum lacunosum-moleculare of the slice in the recording chamber via a mirror coupled to a $60 \times$ objective (1.0 numerical aperture). Flashes were delivered every $60 \mathrm{~s}$, as we found in preliminary experiments that this interstimulus interval produced reliable and stable activation of Cajal-Retzius cells. The number of action potentials elicited by a light flash in Cajal-Retzius cells (directly measured as action currents in the cell-attached configuration) did not change significantly for at least 15 $\min (1.2 \pm 0.1$ action currents during the first $3 \min$ vs $1.2 \pm 0.2$ action 
currents during the last $3 \mathrm{~min}$ of the experiment; $n=7 ; p>0.999$, Wilcoxon matchedpairs signed-rank test). The LED output was driven by transistor-transistor logic output from the Clampex software of the pCLAMP 9.0 program suite (RRID:rid_000085, Molecular Devices).

Post hoc anatomical methods. Cells were filled with biocytin during whole-cell recording and then fixed overnight in $4 \%$ paraformaldehyde in $0.1 \mathrm{M} \mathrm{PB}$ at $4^{\circ} \mathrm{C}$. Endogenous peroxidase activity was quenched with a $3 \%$ $\mathrm{H}_{2} \mathrm{O}_{2}$ solution for 15 min. Sections were incubated overnight at $4^{\circ} \mathrm{C}$ in avidin-biotinylated HRP complex (Vectastain ABC Elite Kit, Vector Laboratories) with $0.1 \%$ Triton X-100 in $\mathrm{PB}$, followed by a peroxidase reaction with $\mathrm{DAB}$ as a chromogen, and intensified with $1 \%$ $\mathrm{NiNH}_{4} \mathrm{SO}_{4}$ and $1 \% \mathrm{CoCl}_{2}$. Slices were postfixed with $0.1 \% \mathrm{OsO}_{4}$ in $\mathrm{PB}(1 \mathrm{~min})$ and then mounted on slides with Moviol (Calbiochem). Cells were reconstructed using a drawing tube (catalog \#452181-9901-000, Zeiss) and digitized using the NeuronJ plugin (RRID:nif0000-00108; Meijering et al., 2004) of the ImageJ software (National Institutes of Health; RRID:nif-0000-30467).

Analysis of electrophysiological recordings. Peak amplitudes, latencies, and kinetic parameters $(20-80 \%$ rise times and half-widths) of synaptic responses were measured and analyzed using the Clampfit 9.0 (RRID: rid_000085, Molecular Devices), Origin Pro 7.0 (RRID:rid_000069, OriginLab), Prism 5 (RRID:rid_000081, GraphPad Software), and Microsoft Excel suites of programs. To reduce the impact of the jitter of the response on peak amplitude and kinetic parameters, measurements shown in Figure 7 were not performed on averaged signals, but on individual waveforms, and then the values obtained for several traces were averaged ( $5 \pm 0$ traces for $n=28$ interneurons, $5 \pm 0$ traces for $n=21$ pyramidal cells). Peak amplitudes were automatically measured by Clampfit using a smoothing window of five samples. Latencies were measured with cursors from the beginning of the light flash. Data used to build and compare the distributions of the basic properties of the responses recorded in interneurons versus pyramidal cells were filtered at $1 \mathrm{kHz}$. Pharmacological experiments were analyzed comparing the properties of responses obtained in control solutions (three to five sweeps, depending on the experiment) versus the ones obtained in the presence of the tested drug and measured in an identical number of traces. When responses were pharmacologically blocked, the values given in the text reflect the peak of the current noise within the time window selected for the analysis. For pharmacological experiments evaluating feedforward currents, peak amplitudes were obtained from the average of $5 \pm 0$ traces in control and $5 \pm 1$ in the presence of the drug ( $n=12$ pyramidal cells). Peak amplitudes were converted in conductances using a $\mathrm{GABA}_{\mathrm{A}}$ reversal potential estimated as described by Aradi and Maccaferri (2004).

A subset of experiments, in which both the absence and presence of a light-evoked response was recorded (P10-P18) was considered for the analysis of the developmental profile of the connection between CajalRetzius cells and their postsynaptic targets. The probability of finding a response shown in Figure 8 was estimated by dividing the number of cells showing a response to light by the overall number of cells tested. A cell was considered to be nonresponsive if light-evoked events could not be observed even using a light flash of $5 \mathrm{~ms}$ duration at maximal intensity.

Statistical methods. Data are presented as mean \pm SE. The significance level was selected as 0.05 , and nonparametric tests were used, as appropriate. Probability values are given rounded off to three decimal places.
Linear fits were weighted according to the number of cells used to estimate the probability of finding a response (see Fig. 8). The specific tests used are explicitly indicated in the text.

Drugs. Drugs were obtained as follows: D-AP-5, NBQX, and gabazine were from Abcam; QX-314 was from Alomone Labs; and murine CXCL12 was from Peprotech. All other drugs were from Sigma-Aldrich.

\section{Results}

Optogenetic activation of cortical hem-derived hippocampal Cajal-Retzius cells

As paired recording-based attempts to study the postsynaptic output of Cajal-Retzius cells have been unsuccessful (in the neocortex: Soda et al., 2003; in the hippocampus: Marchionni et al., 2010), we decided to take advantage of optogenetic techniques (Williams and Deisseroth, 2013). Cortical hem-derived CajalRetzius cells belong to the Wnt3a lineage (Yoshida et al., 2006; Louvi et al., 2007) and settle mostly in the hippocampus (Gu et al., 2011). Therefore, we took advantage of the availability of a Wnt3a-IRES-Cre mouse line (Gil-Sanz et al., 2013) to drive the expression of a channelrhodopsin variant-EYFP fusion protein [ChR2(H134R)-EYFP (ChR); Madisen et al., 2012] in CajalRetzius cells.

As shown in Figure 1, strong EYFP immunoreactivity was detected in a population of cells localized mainly around the hippocampal fissure in stratum lacunosum-moleculare of the CA1 subfield and in the molecular layer of the dentate gyrus (compare Anstötz et al., 2013, their Fig. 4). When observed at high magnification, these cells had the typical characteristics of Cajal-Retzius cells (i.e., tadpole morphology with a single main dendrite and were also endowed with reelin immunoreactivity; 


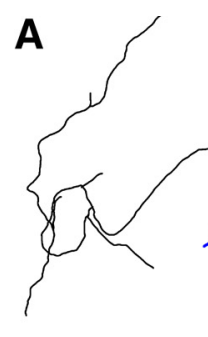

B

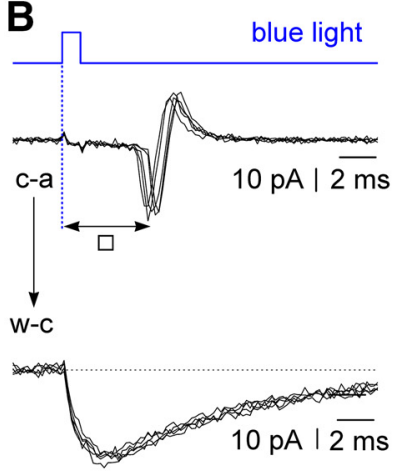

$\mathbf{F}$

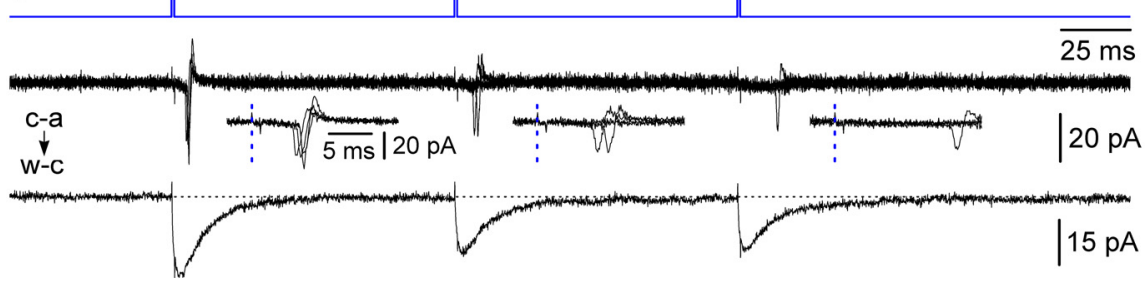

Figure 2. Optogenetically triggered firing in Cajal-Retzius cells. A, Camera lucida tracing of whole-cell, biocytin-filled, EYFPexpressing neurons of stratum lacunosum-moleculare reveals the typical features of Cajal-Retzius (I-m, stratum lacunosummoleculare). $\boldsymbol{B}$, Short flashes of blue light induce action currents in cell-attached configuration ( $c-a$, top traces; five sweeps superimposed) and reveal inward currents after breakthrough into whole-cell voltage-clamp mode ( $w-c, V_{h}=-60 \mathrm{mV}$, bottom traces; five sweeps superimposed). Notice the beginning of the current already during the flash. The empty square indicates latencies measured from the start of the light flash (vertical dotted blue line) to the peak of the action current. The dotted line is for reference. C, Similarly, flashes of blue light trigger firing in the whole-cell current-clamp configuration (five traces superimposed). The empty circle highlights the measurement of the latency from the beginning of the light flash (vertical dotted blue line) to the peak of the action potential. The dotted line indicates the $0 \mathrm{mV}$ level. $\boldsymbol{D}$, Firing pattern of ChR-expressing cells. Notice the sag in the hyperpolarization response $(-25 \mathrm{pA}$ step, $1 \mathrm{~s})$ and the train of action potentials terminated by depolarization block $(70 \mathrm{pA}, 1 \mathrm{~s})$, which is characteristic of Cajal-Retzius cells. The dotted line indicates $-62 \mathrm{mV}$. $\boldsymbol{E}$, Summary plot of the latency of the firing measured under cell-attached ( $c-a$, empty squares) and whole-cell configuration (w-c, empty circles). Both mean $\pm S E$ and individual data points are shown. $\boldsymbol{F}$, Unreliable stimulation by trains of flashes. Notice the decreasing probability of firing coupled with increasing latencies during a $10 \mathrm{~Hz}$ train of flashes delivered to a Cajal-Retzius cell (recoded in cell-attached mode: $c-a$, four traces superimposed). Action currents are expanded in the insets, and the blue dotted lines indicate the start of the flash. Same cell after passing in whole-cell mode ( $\mathrm{w}-\mathrm{c}$ ); notice the decreasing amplitude of the photocurrents during the repeated stimulation. Black dotted line for reference.

Fig. 1; see also Marchionni et al., 2010, 2012; Quattrocolo and Maccaferri, 2013). In addition, weaker immunoreactivity was also present in the granule layer of the dentate gyrus and in the stratum lucidum of the CA3 subfield, consistent with a reported role for Wnt-mediated regulation of dentate gyrus adult neurogenesis (Lie et al., 2005). Similar results were obtained when the hippocampi of five mice were examined.

Within stratum lacunosum-moleculare, the selective expression of ChR by Cajal-Retzius cells was confirmed by biocytin filling of 18 EYFP-expressing neurons (Fig. 2). In all cases, the structure of the recovered cells showed the typical morphology of hippocampal Cajal-Retzius cells, with a single main dendrite and the axon emerging from the opposite pole, as previously described (Marchionni et al., 2010, 2012; Quattrocolo and Maccaferri, 2013). We next verified that light activation of $\mathrm{ChR}$ was able to induce firing in Cajal-Retzius cells both under cellattached and whole-cell configurations (Fig. 2). The latencies from the beginning of the light flash to the peak of the action potential were $4.4 \pm 0.4 \mathrm{~ms}(n=18)$ and $5.6 \pm 0.5 \mathrm{~ms}(n=11)$, respectively, under cell-attached and whole-cell configurations ( $p=0.069$, Mann-Whitney test). However, when trains of light flashes were used, activation of Cajal-Retzius cells became unreliable (Fig. 2). For example, a train of three light flashes delivered at 10 $\mathrm{Hz}$ resulted in different probabilities of firing ( 1.0 for the first pulse, 0.87 for the second pulse, and 0.72 for the third pulse, respectively; $n=9 ; p=0.001$, Friedman test) and increasing latencies $(4.9 \pm 0.5$, $9.2 \pm 0.8$, and $12.3 \pm 0.8 \mathrm{~ms}$, respectively, for the first, second, and third stimuli, $p<$ 0.0001 , Friedman test; $n=9$ ). Therefore, for the remainder of this study, we only used single-flash stimulation.

\section{Cajal-Retzius cell output synapses are glutamatergic}

Having established that ChR expression in Cajal-Retzius cells under our experimental conditions was sufficient to reliably induce firing (following a single flash delivered at low frequencies; for details, see Materials and Methods), we decided to investigate whether optogenetic activation of Cajal-Retzius cells could reveal postsynaptic currents in stratum lacunosummoleculare interneurons. When we recorded from these cells in voltage-clamp mode [holding potential $\left(\mathrm{V}_{\mathrm{h}}\right)=-60$ $\mathrm{mV}]$, the delivery of a flash of blue light generated inward waveforms with the appearance of postsynaptic currents (Fig. 3). Responsive interneurons typically had multipolar short dendrites and local axonal ramifications (Fig. 3). In 11 interneurons, we could recover, to variable degrees, both the somatodendritic structure and the cell axon, whereas in 4 cells, we could recover only the axon and the soma. Their typical location in stratum lacunosum-moleculare, together with their morphological characteristics, suggests that the vast majority of these neurons were neurogliaform cells (Vida et al., 1998).

Next, we designed experiments to test the hypothesis that the waveforms observed in stratum lacunosum-moleculare interneurons were mediated by postsynaptic glutamate receptors (Fig. 4). We took advantage of the fact that AMPA- and NMDAtype glutamate receptors possess very distinct kinetic and pharmacological properties (for review, see Dingledine et al., 1999). When we compared responses recorded at hyperpolarized $(-60$ $\mathrm{mV}$ ) versus depolarized membrane potentials $(+60 \mathrm{mV})$, we noticed clear kinetic differences. Waveforms detected at $-60 \mathrm{mV}$ had a peak amplitude of $57 \pm 15 \mathrm{pA}$, rise times of $1.1 \pm 0.2 \mathrm{~ms}$, and half-widths of $3.8 \pm 0.6 \mathrm{~ms}$, whereas, at a holding potential of $+60 \mathrm{mV}$, we measured peak amplitudes of $72 \pm 16 \mathrm{pA}$, rise times 


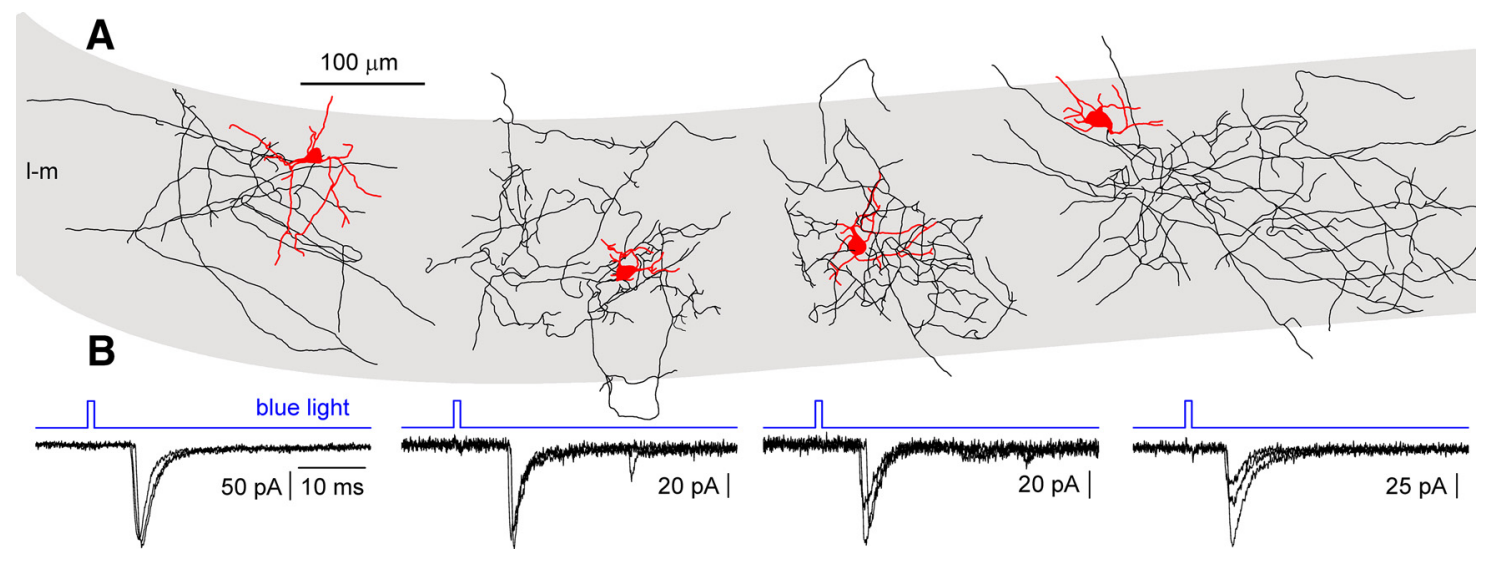

Figure 3. Light stimulation of Cajal-Retzius cells triggers inward currents in stratum lacunosum-moleculare interneurons held in voltage clamp $\left(\mathrm{V}_{\mathrm{h}}=-60 \mathrm{mV}\right)$. $\boldsymbol{A}$, Anatomical reconstruction of four neurogliaform-like cells with local axonal arborization in stratum lacunosum-moleculare (gray area, I-m). Somatodendritic arborization in red, axon in black. $\boldsymbol{B}$, Corresponding postsynaptic currents recorded from the interneurons in $\boldsymbol{A}$ after the delivery of light flashes (blue traces) to stratum lacunosum-moleculare. Three overlapping responses are shown for every neuron.

of $9.7 \pm 2.1 \mathrm{~ms}$, and half-widths of $63.9 \pm$ $9.9 \mathrm{~ms}(n=9$ cells $)$. These results were consistent with the well known voltagedependent block of NMDA receptors by extracellular magnesium (Mayer et al., 1984; Nowak et al., 1984). Responses recorded at hyperpolarized potentials were blocked by the AMPA receptor-specific antagonist NBQX $(20 \mu \mathrm{M})$. Bath application of the antagonist reduced the peak amplitude from $40 \pm 14 \mathrm{pA}$ in control to $5 \pm 2 \mathrm{pA}$ in the presence of the drug $(p=$ 0.004 , Wilcoxon matched-pairs signedrank test; $n=9$ cells). In contrast, when the holding potential was fixed at +60 $\mathrm{mV}$, responses were blocked by the NMDA receptor antagonist D-AP5 (50 $\mu \mathrm{M})$. Addition of D-AP5 reduced the amplitude of the postsynaptic current from a control value of $110 \pm 38$ to $14 \pm 10 \mathrm{pA}$ $(p=0.031$, Wilcoxon matched-pairs signed-rank test; $n=6$ cells).

The most parsimonious explanation for these results is that the AMPA/NMDA receptor-mediated currents in interneurons reflect the binding of glutamate released by Cajal-Retzius cells following their optogenetically triggered firing.

We decided to corroborate this interpretation by taking advantage of the expression of the chemokine (C-X-C motif) receptor 4 (CXCR4) in Cajal-Retzius cells (Stumm et al., 2002, 2003). CXCR4 activation hyperpolarizes Cajal-Retzius cells (Marchionni et al., 2010) via BK-type potassium channels (Marchionni et al., 2012). The CXCR4 receptor agonist, the chemokine CXCL12, would be predicted to reduce the number of spikes produced in Cajal-Retzius cells during optogenetic stimulation. This reduction in presynaptic activity would be also expected to reduce the amplitude of postsynaptic cur-

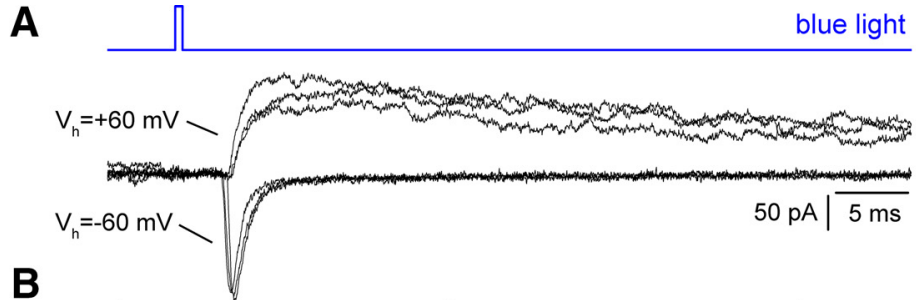

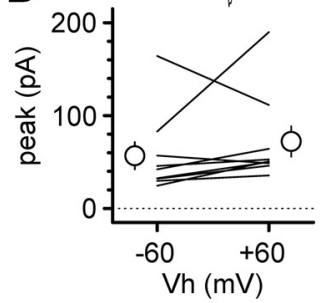

C
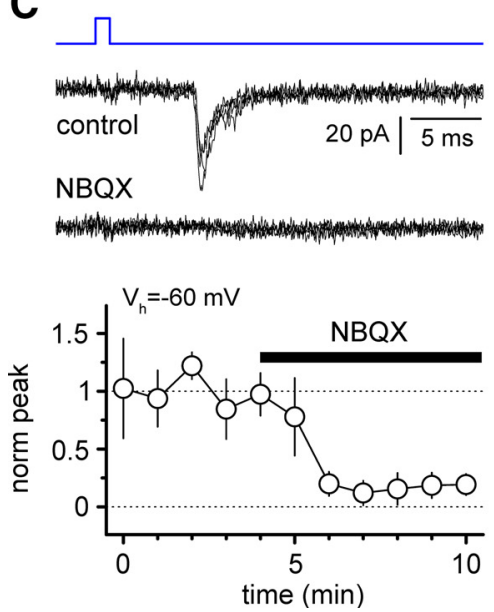
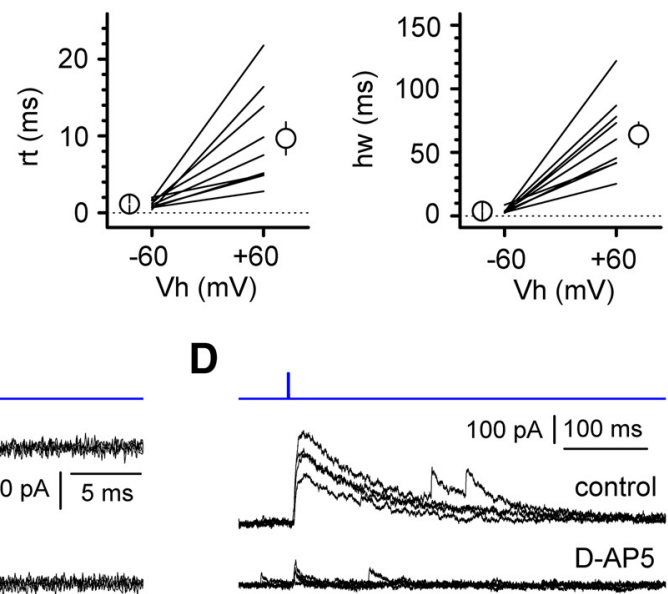

Figure 4. Optogenetic stimulation of Cajal-Retzius cells activates target interneurons via AMPA and NMDA glutamate receptors. $A$, Different holding potentials $\left(V_{h}=-60\right.$ and $\left.+60 \mathrm{mV}\right)$ reveals the presence of kinetically distinct synaptic responses to flashes of blue light. Three sweeps are shown for each holding potential. $\boldsymbol{B}$, Summary plots showing the peak amplitude and kinetic properties ( $r t, 20-80 \%$ rise time; hw, half-width) of synaptic responses recorded in interneurons at hyperpolarized $(-60 \mathrm{mV})$ and depolarized $(+60 \mathrm{mV}$ ) holding potentials. Points joined by lines are data from individual experiments, whereas averages and SE are indicated by empty circles and bars, respectively. C, NBQX $(20 \mu \mathrm{m})$ blocks responses recorded at $-60 \mathrm{mV}$. Top, Postsynaptic currents before and after application of the drug (four sweeps superimposed for every condition). Bottom, Summary plot of the time course of the effect of NBQX application (black bar) on the normalized amplitude of the light-evoked postsynaptic current (norm peak). D, Similar to $\boldsymbol{C}$, but for the D-AP5 sensitivity of responses recorded at $+60 \mathrm{mV}$. 
A
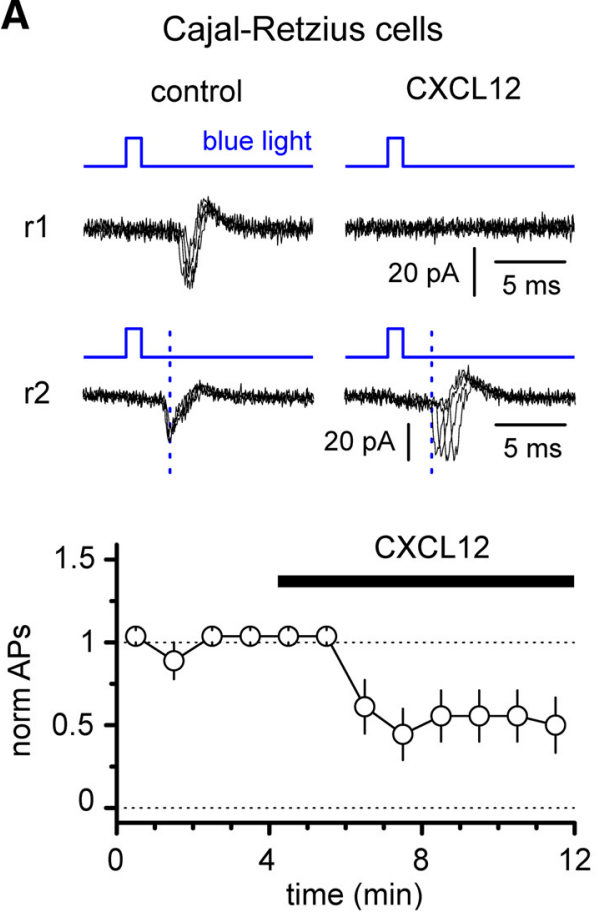

B

interneurons
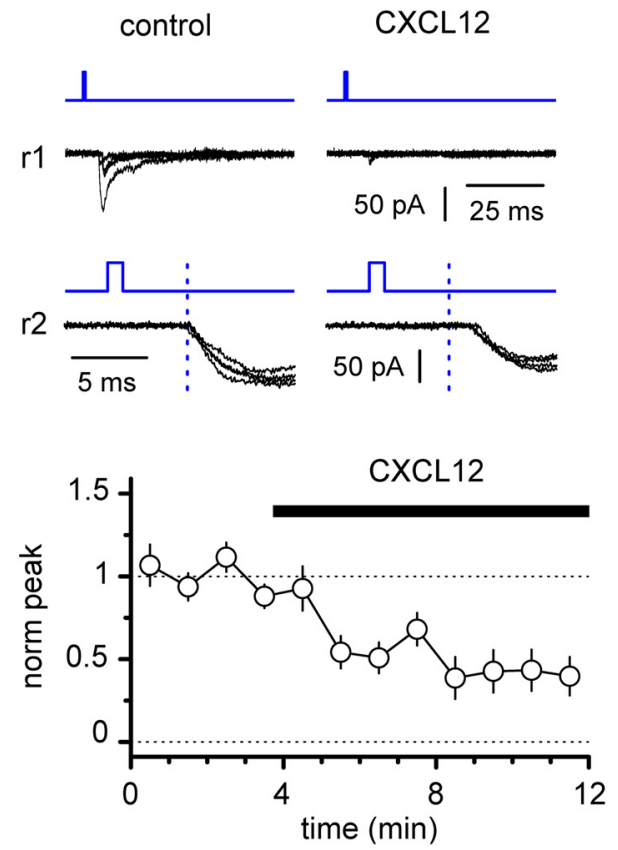

Figure 5. Activation of the CXCR4 receptor has parallel effects on optogenetically triggered excitability of Cajal-Retzius cells and optogenetically evoked postsynaptic responses in stratum lacunosum-moleculare interneurons. A, Bath application of CXCL12 (50 nM) either reduces the number of light-triggered action potentials ( $r 1$, example recording 1) or delays $(r 2$, example recording 2) firing of Cajal-Retzius cells. Top, Insets, The distinct effects are shown by four overlapped sweeps in control and in the presence of CXCL12. The vertical dashed blue lines are for temporal reference. Notice that in the presence of CXCL12 (black bar) the latency of the firing increases in r2. Bottom, Summary graph (empty circles, mean; bars, SE) of the time course of the effect of CXCL12 application on light-evoked spikes in Cajal-Retzius cells (norm APs, normalized number of action potentials). $\boldsymbol{B}$, Similar to $\boldsymbol{A}$, but the analysis is performed on synaptic responses recorded from stratum lacunosum-moleculare interneurons. Notice in the top panels either the abolishment of the synaptic response ( $r 1$, example recording 1 ) or the delay of its onset ( $r 2$, example recording 2). The vertical dashed blue lines are for temporal reference. Bottom, Summary plot of the time course of the normalized peak amplitude (norm peak) of the postsynaptic response during CXCL12 application (black bar).

A

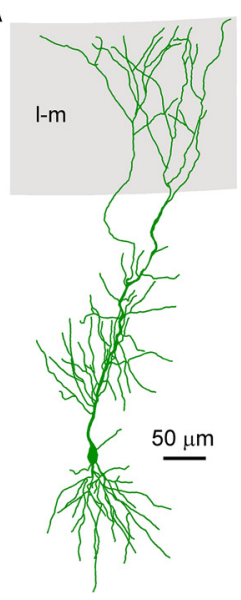

B

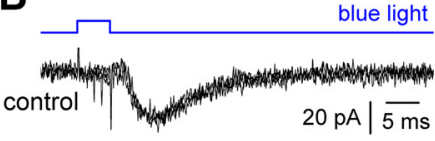

NBQX
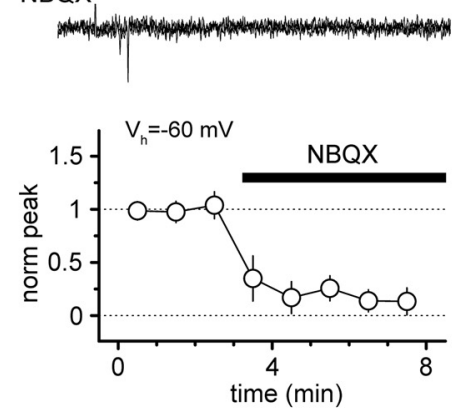

C

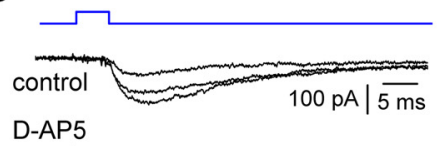

D-AP5
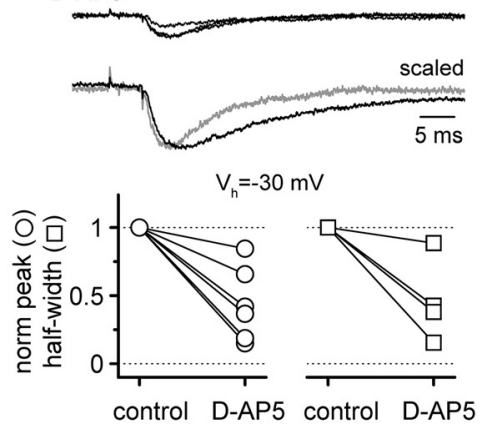

Figure 6. Cajal-Retzius cells contact CA1 pyramidal cells via AMPA and NMDA glutamate receptors. $A$, Anatomical reconstruction of a CA1 pyramidal cell in which a postsynaptic response with a D-AP5-sensitive component was recorded following light stimulation [gray, stratum lacunosum-moleculare (I-m)]. B, Top, Postsynaptic responses recorded at $V_{h}=-60 \mathrm{mV}$ in control conditions and after the addition of NBQX $(20 \mu \mathrm{m})$. Three sweeps are superimposed for each condition. Bottom, Summary plot (empty circles, mean; bars, SE) of the time course of the effect of NBQX application (black bar) on the postsynaptic responses (norm peak, normalized peak). $C$, Top, Postsynaptic responses (three sweeps superimposed) recorded at $V_{h}=-30 \mathrm{mV}$ before and after the application of D-AP5 $(50 \mu \mathrm{M})$. Averaged traces in the two conditions (black trace, control; gray trace, D-AP5) are superimposed after scaling. Bottom, Summary graphs of the effect of D-AP5 on the normalized amplitude (left, norm peak, empty circles are individual experiments) and the half-width (right, empty squares are individual experiments) of the postsynaptic responses.

rents recorded from stratum lacunosum-moleculare interneurons, which do not express the CXCR4 receptor at the developmental stages used in our study (Stumm et al., 2002, 2003; Marchionni et al., 2010) in contrast to pyramidal cells (Shepherd et al., 2012) and granule cells (Kolodziej et al., 2008).
First, we verified that CXCL12 application reduced the number of optogenetically triggered spikes in Cajal-Retzius cells recorded under cell-attached configuration (Fig. 5). As expected, the average number of action potentials generated by the light flash decreased from $1.2 \pm 0.2$ in control to $0.7 \pm 0.2$ in the 
presence of CXCL12 ( $p=0.034$, Wilcoxon matched-pairs signed-rank test; $n=9$ cells). Similarly, application of the chemokine decreased the amplitude of the postsynaptic currents recorded on stratum lacunosum-moleculare interneurons (Fig. 5) from $101 \pm 23 \mathrm{pA}$ in control conditions to $39 \pm 10 \mathrm{pA}$ after its addition to the external solution ( $p=0.001$, Wilcoxon matched-pairs signed-rank test; $n=12$ cells). Because, as mentioned before, stratum lacunosum-moleculare interneurons do not express the CXCR4 receptor, we take this experiment as direct evidence that light-induced responses recorded on interneurons are originated by Cajal-Retzius cells.

Thus, together, our data show that Cajal-Retzius cells form AMPA/NMDA receptor-based excitatory synapses on stratum lacunosum-moleculare interneurons and support previous suggestions of a glutamatergic phenotype (del Río et al., 1995; Hevner et al., 2003; Ina et al., 2007).

While we could reliably reveal synaptic currents in interneurons, responses in pyramidal cells were apparently rarer, and we could observe them only in $14 \%$ of the cases examined (from a sample of 149 cells). When responses were present, they showed similar pharmacological properties to the ones previously described in interneurons (Fig. 6). When pyramidal cells were held at hyperpolarized potentials $(-60 \mathrm{mV})$ synaptic currents were sensitive to NBQX. The amplitude of postsynaptic currents was $37 \pm 10 \mathrm{pA}$ in control conditions when compared with $3 \pm 2 \mathrm{pA}$ in the presence of the drug $(p=0.031$, Wilcoxon matched-pairs signed-rank test; $n=6$ cells). At more depolarized holding potentials $(-30 \mathrm{mV})$, a NMDA receptormediated component was also revealed by bath application of D-AP5. In the presence of the drug, synaptic responses had both reduced peak amplitudes $(22 \pm 8 \mathrm{pA}$ in D-AP5 vs $58 \pm 21 \mathrm{pA}$ in control; $p=0.031$, Wilcoxon matched-pairs signed-rank test; $n=6$ cells) and half-widths (9.6 $\pm 2.7 \mathrm{~ms}$ in D-AP5 vs $32.6 \pm 7.3 \mathrm{~ms}$ in control; $p=0.019$, Mann-Whitney test; $n=6$ cells in control and $n=4$ in D-AP5; in two neurons, responses in D-AP5 were too small to measure kinetics).

The apparent low degree of connectivity between CajalRetzius cells and pyramidal neurons may reflect either an actual targeting bias of Cajal-Retzius cells for interneurons or be the result of the limitations of the stimulation and recording techniques used. In fact, while, in the case of interneurons, the light flashes were delivered to stratum lacunosum-moleculare using the soma of the recorded cell as a reference for the positioning of the objective, in the case of pyramidal cells, the dendrites of the neuron under study were not visible. Therefore, the positioning of the objective was likely to be less accurate with respect to postsynaptic dendrites. Additionally, given the location of the synaptic input to distal dendrites in stratum lacunosum-moleculare, it is also possible that some responses in pyramidal cells were attenuated below detection levels. This would further contribute to the apparent low percentage of pyramidal cells responding to light flashes.

A general comparison of the basic properties of postsynaptic currents recorded in interneurons $(n=28)$ and pyramidal cells $(n=21)$ showed (Fig. 7) the following: indistinguishable distributions of the latencies (from the beginning of the light flash: $6.9 \pm 0.5 \mathrm{~ms}$ in interneurons vs $6.9 \pm 0.5 \mathrm{~ms}$ in pyramidal cells; $p=0.986$, Kolmogorov-Smirnov test); nonstatistically different peak amplitudes $(55 \pm 7 \mathrm{pA}$ in interneurons vs $38 \pm 5 \mathrm{pA}$ in pyramidal cells; $p=0.168$, Kolmogorov-Smirnov test); and very different kinetic parameters. Rise times were $0.6 \pm 0.1 \mathrm{~ms}$ in interneurons compared with $3.4 \pm 0.4 \mathrm{~ms}$ in pyramidal cells $(p<$ 0.0001 , Kolmogorov-Smirnov test), and half-widths were $3.4 \pm$ $0.5 \mathrm{~ms}$ in interneurons compared with $13.8 \pm 1.0 \mathrm{~ms}$ in pyramidal cells $(p<0.0001$, Kolmogorov-Smirnov test).

Together, these data further strengthen a simple interpretation of neurotransmitter release by the same presynaptic neurons (i.e., Cajal-Retzius cells), both onto stratum lacunosummoleculare interneurons and onto the distal dendrites of pyramidal cells. The slower kinetics of responses observed in pyramidal cells are consistent with the dendritic filtering associated with distally generated inputs (Maccaferri et al., 2000), whereas the faster kinetics observed in interneurons suggest synaptic responses originated closer to the somatic recording site (Fig. 3). Furthermore, these data are also consistent with optogenetic stimulation triggering firing in Cajal-Retzius cells after $\sim 5 \mathrm{~ms}$ from the beginning of the light flash (Fig. 2), and the later appear- 


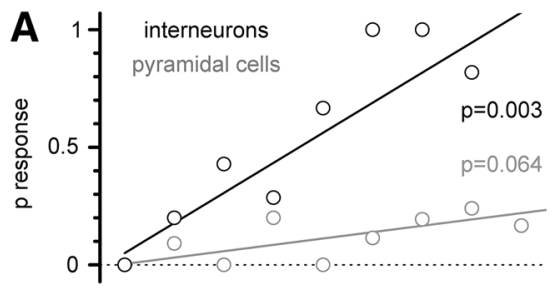

B

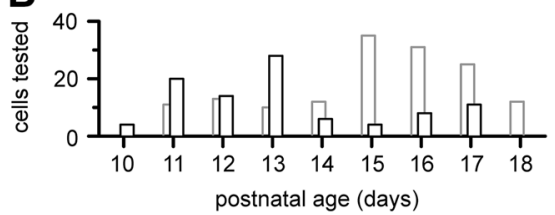

Figure 8. Developmental profile of the probability of finding light-evoked responses in interneurons (black empty circles) versus pyramidal cells (gray empty circles). $\boldsymbol{A}$, Summary plot of the probability of obtaining a response ( $p$ response) and linear fits, weighted according to the number of cells tested at each postnatal age. $\boldsymbol{B}$, Bar plot of the number of interneurons/pyramidal cells (black empty bars/gray empty bars) tested to estimate the probability of obtaining a response.

\section{Are responses recorded on interneurons and pyramidal cells action potential dependent and monosynaptic?}

The proposed simple interpretation of the nature of the postsynaptic currents recorded in interneurons and pyramidal cells, as both originated by Cajal-Retzius cells, is appealing and is supported by several of the results reported above. However, as shown in Figure 1, the expression of ChR in the animal used for our experiments is not limited exclusively to Cajal-Retzius cells. Therefore, we performed additional recordings to rule out the possibility that the observed responses were due to the activation of a polysynaptic circuit. We decided to exclude this possibility by attempting to rescue postsynaptic currents in the presence of TTX by adding the potassium channel blocker 4-AP, similarly to what originally reported by Petreanu et al. (2009). Under these latter conditions, observed responses are interpreted as deriving from the light-induced depolarization of presynaptic terminals in the absence of axonal propagation of action potentials, and hence are incompatible with polysynaptic transmission.

First, we verified that bath application of TTX ( $500 \mathrm{nM})$ could abolish responses both in interneurons and pyramidal cells. As shown in Figure 9, TTX application reduced responses recorded from interneurons from $33 \pm 6 \mathrm{pA}$ in control to $5 \pm 1 \mathrm{pA}$ in the presence of the drug $(p=0.004$, Wilcoxon matched-pairs signed-rank test; $n=$ 9). Similarly, in pyramidal cells, currents were decreased from $48 \pm 16$ to $5 \pm 1 \mathrm{pA}$ following TTX application ( $p=0.016$, Wilcoxon matched-pairs signed-rank test; $n=6)$.

Thus, these results confirmed the supposed TTX sensitivity of the responses, which is a precondition required to study the effects of the combined application of TTX and 4-AP. Also, these data indicate that light-evoked currents are generated by action potential-dependent neurotransmitter release and not by calcium influx into the terminals via ChR.

Next, as shown in Figure 10, we verified that in the presence of both drugs ance of monosynaptic currents after a delay from the peak of the action potential of $\sim 2 \mathrm{~ms}$ (latency from light flash, $\sim 7 \mathrm{~ms}$ ). It also should be pointed out that, because of the very distal location of the input on pyramidal cells, amplitudes of light-evoked currents in these neurons are likely to be much more attenuated than the ones reported for interneurons.

When we took into account the postnatal age of the animal used to prepare the slices (Fig. 8), we found that, while the probability of finding responses in interneurons ( $n=95$ cells examined) was strongly age dependent, this was not the case for pyramidal neurons ( $n=149$ cells examined). This is consistent with the reported presence of growth cones on postnatal Cajal-Retzius cells (Anstötz et al., 2013), which indicates that their axonal targeting of postsynaptic neurons is still being refined postnatally, and with previous work showing that not all Cajal-Retzius cell terminals are facing postsynaptic structures (Marchionni et al., 2010).

Also, this observation suggests that signaling of Cajal-Retzius cells is endowed with postsynaptic target cell specificity, and that the mechanisms and/or the functional properties of the terminals releasing glutamate that activate postsynaptic receptors on interneurons and pyramidal cells may be different.
(TTX, $1 \mu \mathrm{M}$; 4-AP, $1 \mathrm{~mm}$ ) no action potential was recorded in Cajal-Retzius cells. As expected, the number of action potentials recorded in response to a flash of light in Cajal-Retzius cells was $1.5 \pm 0.2$ in control conditions versus $0.0 \pm 0.0$ in the presence of the drugs ( $p=0.021$, Wilcoxon matched-pairs signed-rank test; $n=7$ neurons).

When we monitored the effects of the combined application of TTX and 4-AP on responses recorded from interneurons (Fig. 10 ), we noticed that, despite an initial decline, the amplitude of the light-induced current returned to control levels $(273 \pm 50 \mathrm{pA}$ in the absence of the drugs compared with $219 \pm 44 \mathrm{pA}$ in the presence of TTX and 4-AP ( $p=0.151$, Wilcoxon matched-pairs signed-rank test; $n=12$ cells). In contrast, when the same experiment was performed on pyramidal cells (Fig. 10), perfusion of an external solution containing TTX and 4-AP resulted in the complete abolishment of the light-induced response $(51 \pm 11 \mathrm{pA}$ in control vs $1 \pm 2 \mathrm{pA}$ in the presence of the drugs; $p=0.016 ; n=7$ neurons). These results confirmed that light-induced currents recorded on interneurons are generated by monosynaptic transmission and suggest that responses observed on pyramidal cells are either the result of the activation of a polysynaptic circuit or are generated by terminals with different 
A

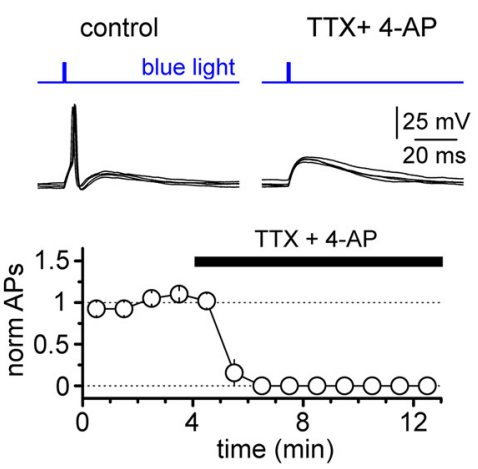

B

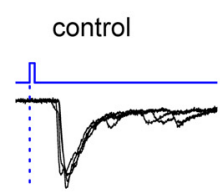

$T T X+4-A P$
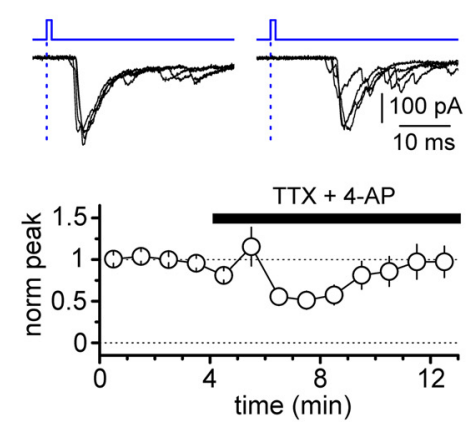

C pyramidal cells
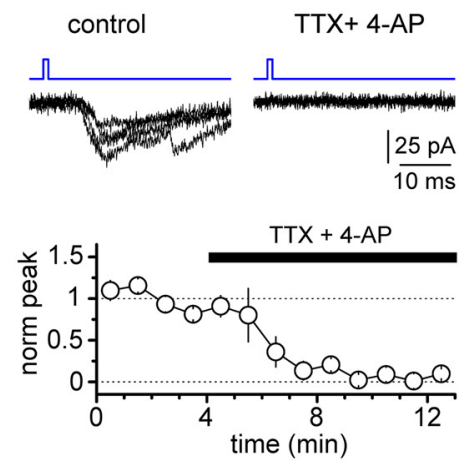

Figure 10. Effects of combined application of TTX $(1 \mu \mathrm{M})$ and 4-AP (1 mM) on light-evoked action potential in Cajal-Retzius cells, and light-evoked synaptic currents in interneurons and pyramidal cells. A, Top, Light-evoked action potentials in Cajal-Retzius cells are prevented by adding TTX and 4-AP (black bar) to the external solution (four sweeps superimposed in both conditions). Bottom, Summary plot showing the time course of the effect (norm APs, normalized number of action potentials; empty circles and bars, mean and SE). $\boldsymbol{B}$, Top, Light-evoked synaptic currents in interneurons are not abolished by the combined application of TTX and 4-AP. Notice however, the increased latency of the light-evoked events (dotted blue line indicates the beginning of the light flash for reference). Four responses superimposed in both condition. Bottom, Summary graph form several experiments (norm peak, normalized peak of the synaptic response). $\boldsymbol{C}$, As in $\boldsymbol{B}$; however, notice that the application of TTX and 4-AP completely abolishes responses in pyramidal neurons.

A

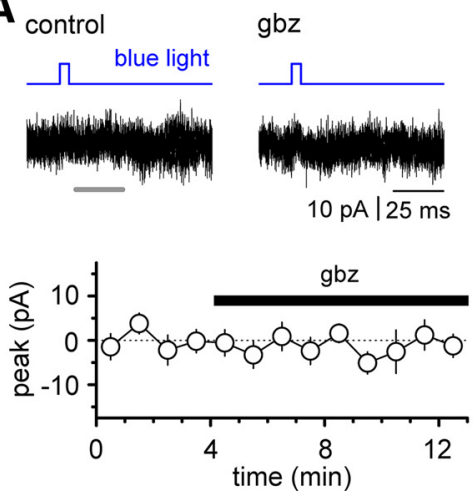

B
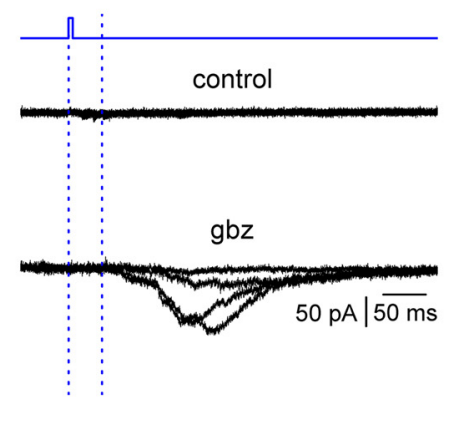

C
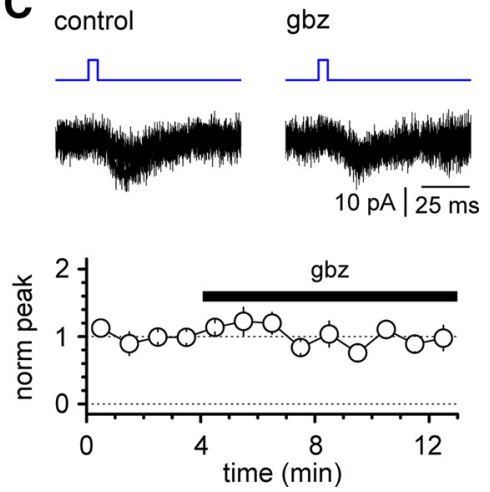

Figure 11. Effects of suppressing fast GABAergic inhibition on light-evoked responses in pyramidal cells. $\boldsymbol{A}$, Top, Traces from a nonresponsive pyramidal cell in control conditions and in the presence of gabazine (gbz; $12.5 \mu \mathrm{M})$. Notice that gabazine application does not reveal latent polysynaptic pathway. The gray line shows the time window used to measure the peak current following the light flash. Four sweeps were superimposed in both condition. Bottom, Summary plot from 9 of 10 pyramidal neurons that did not produce light-evoked currents either in the control condition or after the addition of gabazine (empty circles, mean; bars, SE). B, Sweeps from the single experiment where gabazine application unmasked latent polysynaptic pathways. Top, Four traces superimposed in control conditions. Bottom, Four records in the presence of gabazine. Notice the long latency from the beginning of the light flash (dotted blue lines for reference), which is incompatible with the much shorter latencies usually recorded in light-responsive pyramidal cells (compare Fig. 7). C, Top, Light-evoked responses in pyramidal cells in control conditions and after the addition of gabazine. Four sweeps were superimposed in both condition. Notice that responses are unchanged by the addition of the drug. Bottom, Summary graph for all the responsive cells tested (norm peak, normalized peak of the synaptic response; empty circles and bars, mean and SE, respectively). The mice used for these experiments $(n=3)$ were selected at a postnatal stage associated with GABA $A_{A}$ receptor-mediated inhibition in hippocampal pyramidal neurons (P15, P17, and P18; see Banke and McBain, 2006).

properties, which prevent a sufficient activation by light flashes even in the presence of TTX and 4-AP.

The functional emergence of polysynaptic circuits is classically regulated by fast GABAergic inhibition (Miles and Wong, 1987). Therefore, if responses recorded on pyramidal cells were due to polysynaptic circuits, we predicted that application of a $\mathrm{GABA}_{\mathrm{A}}$ receptor antagonist would either reveal responses in pyramidal neurons originally silent to light stimulation and/or strengthen the observed responses in pyramidal cells already sensitive to light stimulation (Fig. 11). Application of gabazine (12.5 $\mu \mathrm{M})$ did not unmask latent polysynaptic responses in 9 of 10 recordings. The peak current measured in control conditions was $0 \pm 0 \mathrm{pA}$ versus $-2 \pm 3 \mathrm{pA}$ in the presence of the antagonist $(p=$ 0.910 , Wilcoxon matched-pairs signed-rank test; $n=9$ cells). Interestingly, in the only recording revealing the appearance of polysynaptic transmission, the latency of the unmasked response was longer than $40 \mathrm{~ms}$, which appears incompatible with the latency values measured in responsive cells under control condi- tions ( $\sim 7 \mathrm{~ms}$; Fig. 7). Last, gabazine did not alter the amplitude of responses in pyramidal cells that were sensitive to light stimulation $(9 \pm 1 \mathrm{pA}$ in control vs $8 \pm 1 \mathrm{pA}$ in gabazine; $p=0.313$, Wilcoxon matched-pairs signed-rank test; $n=6$ neurons).

Thus, our overall results converge in indicating that responses observed in interneurons are generated by monosynaptic connections originated from Cajal-Retzius cells. However, despite the failure of the TTX plus 4-AP test, it is also unlikely that responses recorded on pyramidal neurons are the result of polysynaptic activation, and we favor the hypothesis that they are generated by monosynaptic mechanisms (albeit different from the ones generating responses in interneurons; see Discussion).

In principle, monosynaptic responses could also be generated by direct light activation of long-range glutamatergic axons targeting stratum lacunosum-moleculare that do not belong to Cajal-Retzius cells. This layer, in particular, is mostly targeted by layer II/III pyramidal neurons of the entorhinal cortex (Steward 

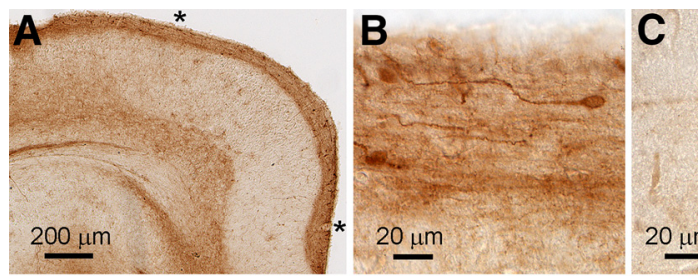

D

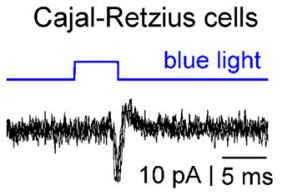

entorhinal cortex neurons
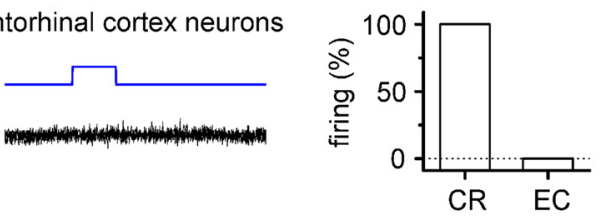

E Cajal-Retzius cells
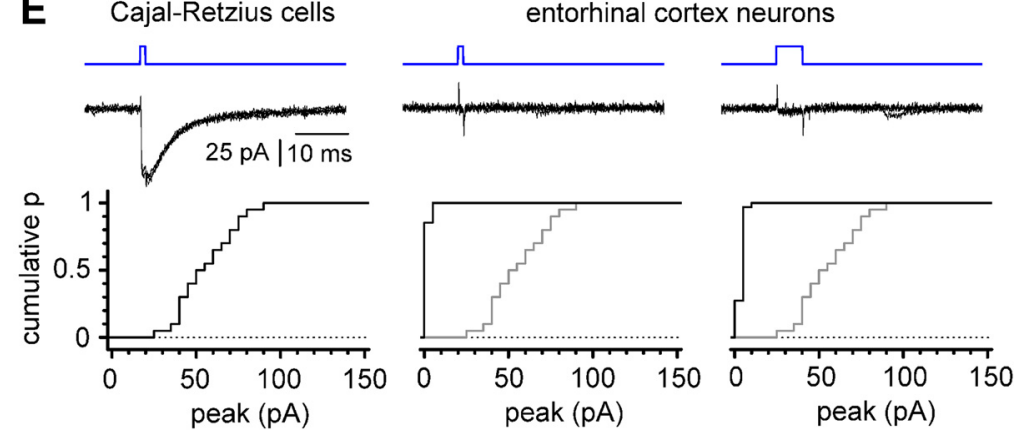

Figure 12. Lack of direct light-evoked firing and of ChR expression in entorhinal cortex neurons. $A$, Immunocytochemistry showing EYFP labeling of layer I in the entorhinal cortex, but no clearly labeled neurons in the deeper layers. $\boldsymbol{B}, \boldsymbol{C}$, Enlargements of the areas marked by an asterisk in $\boldsymbol{A}$ for the lateral and medial entorhinal cortices, respectively. Notice the typical morphology of Cajal-Retzius cells and the staining associated with layer I. D, Comparison of the response to light in hippocampal Cajal-Retzius neurons (left) versus layer II/III entorhinal cortex cells (middle) in cell-attached conditions. Notice the reliable firing reflected by action currents in Cajal-Retzius cells and the lack of light-induced effects in entorhinal cortex neurons. Four sweeps superimposed in both cases. Right, The percentage of cells responding to light with firing in the two different samples. CR, Cajal-Retzius cells; EC, entorhinal cortex neurons. Notice that entorhinal cortex neurons do not fire under these experimental conditions. $\boldsymbol{E}$, ChR-mediated currents in hippocampal Cajal-Retzius cells (left), and layer II/III entorhinal cortex neurons (middle and right). A short flash of light (1 ms) produces significant currents in Cajal-Retzius cells, as shown by the recording (four traces superimposed, top) and by the cumulative distribution plot for several experiments (bottom). In contrast, light flashes either of the same (1 ms; middle) or of longer duration (5 ms; right) do not produce significant currents in entorhinal neurons. Top, Four traces superimposed showing the response of entorhinal cortex neurons to 1 and 5 ms flashes. Bottom, Summary plots for the two conditions (the distribution of the photocurrents in Cajal-Retzius cells is also shown in gray for comparison).

and Scoville, 1976; Kitamura et al., 2014). Although these cells are not derivatives of the Wnt3a lineage (Louvi et al., 2007) and did not show any significant EYFP labeling (Fig. 12), we decided to exclude their potential involvement in our results by ruling out that light flashes might directly trigger their firing.

After blocking synaptic transmission with $\mathrm{Cd}^{2+}(200 \mu \mathrm{M})$, we delivered 5-ms-long light flashes at maximal intensity to hippocampal Cajal-Retzius cells (Fig. 12). All cells responded by generating action currents in cell-attached conditions $(n=10$ cells). In contrast, when identical recordings were performed from neurons located in layer II/III of the entorhinal cortex, firing was never observed ( $n=15$ neurons; $p<0.0001$, Fisher's exact test). In addition, we compared the functional expression of ChR in hippocampal Cajal-Retzius cells versus entorhinal neurons by taking advantage of voltage-clamp recordings $\left(\mathrm{V}_{\mathrm{h}}=-60\right.$ $\mathrm{mV}$; Fig. 12). After blocking synaptic transmission with TTX (500 nM), a 1-ms-long pulse of blue light delivered onto Cajal-Retzius cells at maximal intensity evoked currents with an amplitude of $58 \pm 4 \mathrm{pA}(n=20)$, which compared with $4 \pm 0 \mathrm{pA}$ under identical conditions in principal neurons of the entorhinal cortex neurons $(p<0.0001$, Mann-Whitney test; $n=34)$. Even increasing the duration of the flash to $5 \mathrm{~ms}$ generated minimal currents $(6 \pm 0$
$\mathrm{pA} ; n=33$ neurons). Together, our results indicate that, under our experimental conditions, entorhinal neurons are not the source of optogenetically triggered monosynaptic input to hippocampal stratum lacunosum-moleculare interneurons and pyramidal cells, and reinforce our interpretation that light-induced responses are the direct result of neurotransmitters released by Cajal-Retzius cells.

To our knowledge, beyond the main glutamatergic input originating from the entorhinal cortex, stratum lacunosummoleculare receives only additional excitation from the thalamic midline nuclei (reuniens and rhomboid; for review, see Cassel et al., 2013). However, both nuclei have been reported to be only sparsely populated by Wnt3a derivatives (Louvi et al., 2007), and no thalamic expression of CXCR4 mRNA at the postnatal stages used in our study has been reported (Tissir et al., 2004). Therefore, we think that, under our experimental conditions, contamination from thalamic responses is unlikely.

\section{A novel hippocampal feedforward GABAergic circuit driven by Cajal-Retzius cells}

Thus, if Cajal-Retzius cells can excite both interneurons and pyramidal cells, we predicted that suprathreshold EPSPs in interneurons could drive disynaptic GABAergic input onto pyramidal cells (Fig. 13). When we recorded from pyramidal cells, under experimental conditions designed to highlight GABAergic inputs [using either chloride-loaded pipettes and hyperpolarized holding potentials $\left(\mathrm{V}_{\mathrm{h}}=-60 \mathrm{mV}\right)$ or electrodes with low chloride content and depolarized holding potentials $\left(\mathrm{V}_{\mathrm{h}}=0 \mathrm{mV}\right)$; for further details, see Materials and Methods and the legend of Fig. 13], we could detect synaptic responses with long latencies $(12.7 \pm 0.9 \mathrm{~ms}$ from the beginning of the light flash; $n=8$ ). Keeping in consideration that optogenetic activation of Cajal-Retzius cells takes $\sim 5 \mathrm{~ms}$ (from the beginning of the light flash to action potential peak; see Fig. 2), and that the beginning of glutamatergic postsynaptic currents in interneurons and pyramidal cells occurs after an $\sim 2$ ms synaptic delay ( $\sim 7 \mathrm{~ms}$ from the beginning of the light flash; Fig. 7 ), the long synaptic latency observed here $(\sim 8 \mathrm{~ms}$ from action potential peak and $\sim 13 \mathrm{~ms}$ from the beginning of the light flash) seemed incompatible with a monosynaptic response. In fact, it did strongly suggest to us the possibility of a Cajal-Retzius cell-driven polysynaptic circuit.

Therefore, we tested the possibility that optogenetically triggered responses in interneurons could reach firing threshold and generate a disynaptic feedforward GABAergic input of pyramidal neurons. This input would be predicted to be abolished both by $\mathrm{GABA}_{\mathrm{A}}$ and AMPA receptor antagonists (Fig. 13).

We began by testing the sensitivity of these long-latency currents to the $\mathrm{GABA}_{\mathrm{A}}$ receptor antagonist gabazine. The calculated conductance of these responses was $3.3 \pm 1.1 \mathrm{nS}$ in control vs 
$0.1 \pm 0.2 \mathrm{nS}$ in the presence of the drug (12.5 $\mu \mathrm{M} ; p=0.031$, Wilcoxon matchedpairs signed-rank test; $n=6$ ). In a second set of experiments, we verified that longlatency currents were also decreased by the AMPA receptor blocker NBQX. We measured a conductance of $3.8 \pm 0.9 \mathrm{nS}$ in control conditions, which compared with a value of $0.1 \pm 0.1 \mathrm{nS}$ after the addition of NBQX (20 $\mu \mathrm{M} ; p=0.031$, Wilcoxon matched pairs signed rank test; $n=6$ ).

Thus, both the latency measured and the pharmacological sensitivity of the recorded currents confirm the presence of a novel feedforward network in the developing hippocampus, which is driven by Cajal-Retzius cells.

\section{Discussion}

Our major conclusions are as follows: (1) Cajal-Retzius cells are excitatory neurons activating both AMPA- and NMDA-type glutamate receptors; (2) Cajal-Retzius cells impact both GABAergic interneurons and pyramidal cells; and (3) Cajal-Retzius cells activate a newly defined feedforward GABAergic circuit in pyramidal neurons.

Overall, our data indicate that CajalRetzius cells form a novel glutamatergic microcircuit (Fig. 14).

\section{Cajal-Retzius cells in the hippocampal network}

Cajal-Retzius cells originate from multiple sites at the borders of the developing pallium and are distinguished by molecular markers defining their lineage (Bielle et al., 2005; Griveau et al., 2010). For example, Cajal-Retzius cells derived from the cortical hem originate from Wnt3a-expressing precursors (Louvi et al., 2007), and the Wnt3a-IRES-Cre mouse has been already shown to be a valuable tool for their manipulation (Gil-Sanz et al., 2013). We took advantage of optogenetic techniques to explore the significance of a synapse that had not been studied by electrophysiological means before. Our data show that Cajal-Retzius cells may play a dual role. On the one hand, they activate glutamate receptors on pyramidal cells, but, on the other hand, their connectivity to GABAergic interneurons may result in feedforward GABAergic input. While the impact of their monosynaptic output would be predicted to be always excitatory, because it depends on AMPA- and NMDA-type glutamate receptors, the role of Cajal-Retzius cell-driven GABAergic output may be more complex.

First, while synaptically released GABA usually results in inhibitory effects in the adult brain (but for a more precise definition of GABAergic inhibition, see Bernard et al., 2000), its physiological roles during development are more variable, when both excitation and inhibition have been reported, depending on the specific postnatal ages and regions examined (Rivera et al., 1999; Glykys et al., 2009). Another important aspect that needs to be considered is that, during trains of action potentials, the reciprocal relationships between the short-term dynamics of monosynaptic glutamatergic excitation and feedforward inhibition will be the final determinant of the overall effects of Cajal-Retzius cells. For example, a frequency-dependent switch from inhibition to excitation was reported in the CA3 hippocampus following activation of the mossy fiber synapse, due to the coupling of a direct mossy fiber-pyramidal neuron synapse with strong short-term facilitation, with feedforward GABAergic output characterized by strong short-term depression (Mori et al., 2004; see also Torborg et al., 2010). Our work shows that Cajal-Retzius cells excite neurogliaform cells of stratum lacunosum-moleculare, whose output to target neurons is strongly modulated by short-term depression (Karayannis et al., 2010). Therefore, this would predict the progressive reduction of Cajal-Retzius cells-driven feedforward GABAergic input following prolonged firing. Thus, network states such as theta oscillations, which generate rhythmic firing in neurogliaform and O-LM interneurons (Klausberger et al., 2003; Fuentealba et al., 2010; Varga et al., 2012), would be expected to be associated with a stronger GABAergic input to pyramidal cell distal dendrites originated by O-LM cells, which are less sensitive to short-term depression than neurogliaform cells (Maccaferri et al., 2000; Losonczy et al., 2002). At the same time, O-LM cell-dependent GABAergic input to CajalRetzius cell would be expected to generate excitation and firing of these latter neurons via depolarizing GABAergic signaling (Quattrocolo and Maccaferri, 2013), and lead to enhanced glutamate release on the distal dendrites of pyramidal cells during a network 


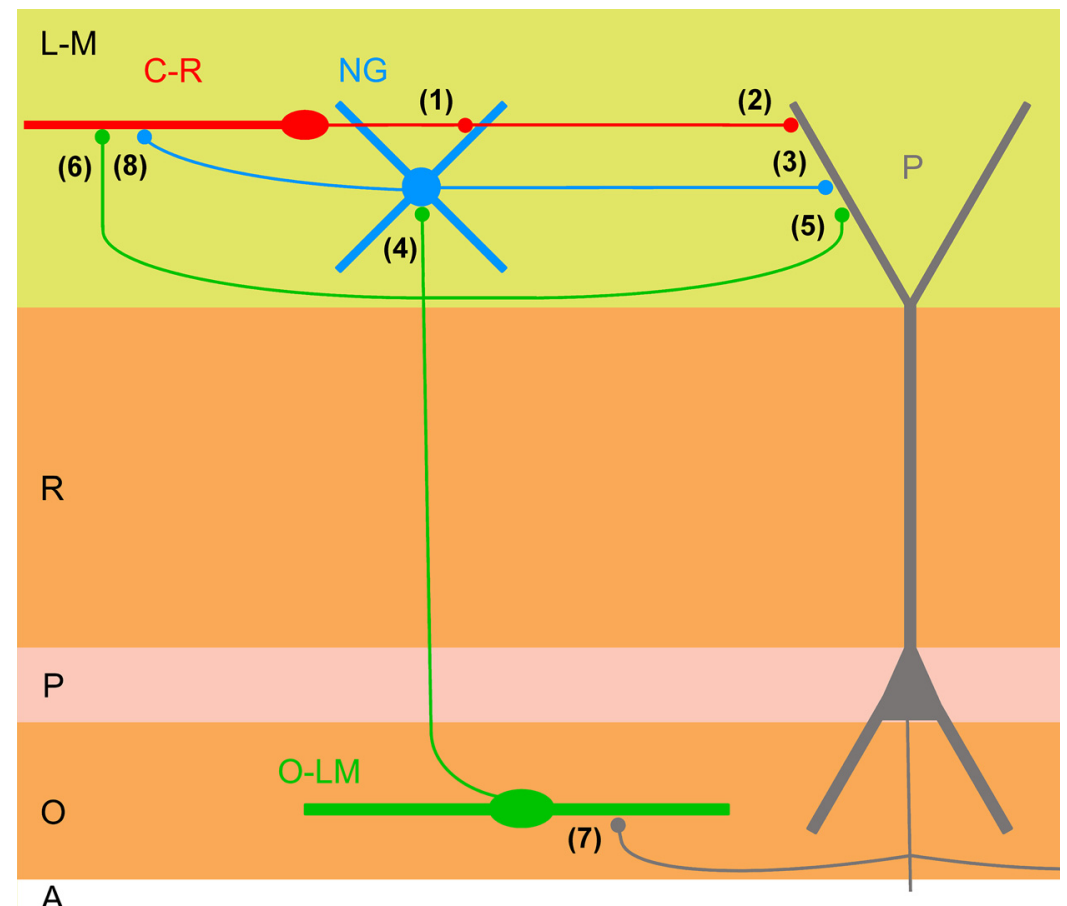

Figure 14. Cajal-Retzius cells within the hippocampal circuit. We identified Cajal-Retzius cells (C-R) as a novel source of glutamatergic inputs for neurogliaform cells (NG; synapse indicated by 1 ) and pyramidal cells ( $P$; synapse indicated by 2; but notice that the possibility that different types of Cajal-Retzius cells target either interneurons or pyramidal cells cannot be excluded; also, please see Discussion for the possibility of spillover). In addition, Cajal-Retzius cells, through the modulation of the interneurons activity, are able to drive a powerful disynaptic inhibition on pyramidal cells (synapse 3; for a review of the neurogliaform-pyramidal cells connection, see Capogna and Pearce, 2011). Data in the literature show that neurogliaform cells activity can be modulated by inputs from 0 -LM cells (synapse 4; Elfant et al., 2008), which also provides GABAergic inhibitory inputs to pyramidal cells (synapse indicated by 5; Maccaferri et al., 2000) and GABAergic excitatory inputs to Cajal-Retzius cells (synapse indicated by 6; Quattrocolo and Maccaferri, 2013). 0-LM cells create a feedback inhibitory loop with pyramidal cells, which are their main source of excitatory inputs (synapse indicated by 7; Ali and Thomson, 1998; Losonczy et al., 2002). The activity of Cajal-Retzius cells can also be modulated by GABAergic inputs from neurogliaform cells (synapse indicated by 8; Quattrocolo and Maccaferri, 2013), whose final effect depends on the level of polarization of the membrane of Cajal-Retzius cells. L-M, stratum lacunosum-moleculare; R, Stratum radiatum; $P$, stratum pyramidale; 0 , stratum oriens; $A$, alveus.

state usually associated with enhanced synaptic plasticity (Huerta and Lisman, 1993).

\section{Presynaptic and postsynaptic receptor mechanisms involved in Cajal-Retzius cell signaling}

Our experimental results show that Cajal-Retzius cells activate glutamate receptors both on interneurons and pyramidal cells. However, different mechanisms are likely to be involved. In fact, in contrast to light-induced responses observed on interneurons, which passed the TTX/4-AP test for monosynaptic transmission, this was not the case for currents recorded on pyramidal cells. However, responses on pyramidal cells also failed the gabazine test for polysynaptic transmission. Furthermore, in the single case in which polysynaptic currents were revealed, their latency was too long to be compatible with light-dependent responses (which had identical latencies to monosynaptic responses recorded from interneurons). Several possibilities can be proposed. First, Cajal-Retzius cell terminals contacting pyramidal cells may express a different repertoire/density of voltagedependent conductances so that ChR activation in the presence of 4-AP does not produce calcium influxes sufficient to overcome blockade of sodium channels by TTX. This would not be surprising, as target cell-specific properties of synaptic terminals have already been described at various connections
(Maccaferri et al., 1998; Reyes et al., 1998). Another possibility is that responses observed on pyramidal cells are actually the result of glutamate spillover from synchronous activation of many terminals lacking postsynaptic targets (Marchionni et al., 2010). Although glutamate spillover is most usually associated with activation of NMDA receptors, several reports have shown that it may also reach concentrations sufficient to activate AMPA receptors (Carter and Regehr, 2000; DiGregorio et al., 2002; Szapiro and Barbour, 2007). This mechanism might require a high degree of release synchronicity from many terminals, which may be provided by fast signals such as physiological action potentials and be disrupted in their absence. This possibility would also explain why responses in pyramidal cells were not found as frequently as in interneurons and had a different developmental regulation.

What could be the computational role of Cajal-Retzius cell glutamatergic signaling? Because of their calcium permeability (MacDermott et al., 1986), NMDA receptors have been associated with various forms of synaptic plasticity such as longterm potentiation and long-term depression (Lüscher and Malenka, 2012). This suggests the possibility that Cajal-Retzius cell-dependent signaling may be in involved in the dynamic regulation of synaptic weights in the stratum lacunosummoleculare microcircuit.

We can imagine that coincident activity in Cajal-Retzius cells and in temporoammonic afferents may act as an associative signal for NMDA receptor-dependent plasticity such as insertion of AMPA receptors in silent synapses (Durand et al., 1996), which are largely present in immature cortical networks (Hanse et al., 2013). This could occur following spontaneous action potentials in immature pyramidal cells (Spigelman et al., 1992; Shao and Dudek, 2009), which would activate Cajal-Retzius cells via a disynaptic pathway involving first the pyramidal-O-LM interneurons synapse (Ali and Thomson, 1998) and then the O-LM-CajalRetzius cell connection (Quattrocolo and Maccaferri, 2013).

Strengthening/maturation of temporoammonic synapses is likely to be important for the increase in the number of hippocampal neurons acquiring the properties of place cells and/or for the refining of their spatial-dependent firing. Both of these phenomena have been reported to occur during the first 2-3 postnatal weeks in rodents pups (Langston et al., 2010; Wills et al., 2010), when Cajal-Retzius cells are still abundantly present in the stratum lacunosum-moleculare microcircuit (Supèr et al., 1998; Marchionni et al., 2010). In fact, it is important to note that, in contrast to Cajal-Retzius cells of the neocortex, which decrease in numbers until they disappear within the first 2 postnatal weeks (Chowdhury et al., 2010), Cajal-Retzius cells of the hippocampus persist for much longer and have been found occasionally even in 
adult animals of several species (Drakew et al., 1998; Supèr et al., 1998; Abraham and Meyer, 2003; Abrahám et al., 2004).

\section{Cajal-Retzius cells, dendritic development, and cellular migration}

The synaptotrophic theory (Cline and Haas, 2008) postulates that glutamate, acting on postsynaptic receptors, can have an important impact on the maturation of the structural and functional properties of growing dendrites. For example, glutamate has been shown to promote dendritic growth and spine development in several brain areas of different organisms (Vaughn et al., 1988; Rajan and Cline, 1998; Portera-Cailliau et al., 2003; De Marco García et al., 2011; Kwon and Sabatini, 2011). Could glutamate released by Cajal-Retzius cells play such a role? Interestingly, Cajal-Retzius cells have been reported to express selectively vesicular glutamate transporter 2 (Yamazaki et al., 2004; Ina et al., 2007). When this molecule was genetically ablated in the telencephalon, and hence the glutamate-dependent functions of Cajal-Retzius cells were likely eliminated, dendritic length and spine density of hippocampal pyramidal neurons were reduced, and deficits of synaptic transmission, plasticity, and spatial learning were observed (He et al., 2012).

Therefore, we propose that glutamate released by CajalRetzius cells may be involved in the maturation of postsynaptic elements of the stratum lacunosum-moleculare circuitry (i.e., distal dendrites of pyramidal cells and overall dendritic arbors of local interneurons).

Furthermore, at early developmental stages, neurotransmitters may act in a paracrine fashion and regulate neuronal migration (for review, see Manent and Represa, 2007). For example, glutamate has been shown to regulate the migration of hippocampal interneurons via AMPA receptors (Manent et al., 2006), whereas modulation of pyramidal cell migration appears to be controlled by $\mathrm{GABA}_{\mathrm{A}}$ and NMDA receptors (Manent et al., 2005). Glutamate originating from hippocampal Cajal-Retzius cells might play a pivotal role in orchestrating a coordinated and balanced positioning of both cell types. Further investigation of the hippocampal cellular architecture in mice with functionally inactivated Cajal-Retzius cells will be required to explore this issue.

\section{Conclusions}

Our work has unveiled a novel network, which could play significant roles in hippocampal development and integration. These new findings will allow the design and testing of hypothesisdriven experiments, providing further insights into hippocampal physiological functions and, potentially, into unexplored mechanisms of disease.

\section{References}

Abraham H, Meyer G (2003) Reelin-expressing neurons in the postnatal and adult human hippocampal formation. Hippocampus 13:715-727. CrossRef Medline

Abrahám H, Tóth Z, Seress L (2004) A novel population of calretininpositive neurons comprises reelin-positive Cajal-Retzius cells in the hippocampal formation of the adult domestic pig. Hippocampus 14:385401. CrossRef Medline

Ahmed OJ, Mehta MR (2009) The hippocampal rate code: anatomy, physiology and theory. Trends Neurosci 32:329-338. CrossRef Medline

Ali AB, Thomson AM (1998) Facilitating pyramid to horizontal oriensalveus interneurone inputs: dual intracellular recordings in slices of rat hippocampus. J Physiol 507:185-199. CrossRef Medline

Anstötz M, Cosgrove KE, Hack I, Mugnaini E, Maccaferri G, Lübke JH (2013) Morphology, input-output relations and synaptic connectivity of Cajal-Retzius cells in layer 1 of the developing neocortex of CXCR4-EGFP mice. Brain Struct Funct. Advance online publication. Retrieved August 19, 2014. doi: 10.1007/s00429-013-0627-2. CrossRef Medline

Aradi I, Maccaferri G (2004) Cell type-specific synaptic dynamics of synchronized bursting in the juvenile CA3 rat hippocampus. J Neurosci 24: 9681-9692. CrossRef Medline

Armstrong C, Krook-Magnuson E, Soltesz I (2012) Neurogliaform and ivy cells: a major family of nNOS expressing GABAergic neurons. Front Neural Circuits 6:23. CrossRef Medline

Banke TG, McBain CJ (2006) GABAergic input onto CA3 hippocampal interneurons remains shunting throughout development. J Neurosci 26: 11720-11725. CrossRef Medline

Bernard C, Cossart R, Hirsch JC, Esclapez M, Ben-Ari Y (2000) What is GABAergic inhibition? How is it modified in epilepsy? Epilepsia 41 [Suppl 6]:S90-S95. Medline

Bielle F, Griveau A, Narboux-Nême N, Vigneau S, Sigrist M, Arber S, Wassef M, Pierani A (2005) Multiple origins of Cajal-Retzius cells at the borders of the developing pallium. Nat Neurosci 8:1002-1012. CrossRef Medline

Borrell V, Pujadas L, Simó S, Durà D, Solé M, Cooper JA, Del Río JA, Soriano E (2007) Reelin and mDabl regulate the development of hippocampal connections. Mol Cell Neurosci 36:158-173. CrossRef Medline

Capogna M (2011) Neurogliaform cells and other interneurons of stratum lacunosum-moleculare gate entorhinal-hippocampal dialogue. J Physiol 589:1875-1883. CrossRef Medline

Capogna M, Pearce RA (2011) GABA A,slow: causes and consequences. Trends Neurosci 34:101-112. CrossRef Medline

Carter AG, Regehr WG (2000) Prolonged synaptic currents and glutamate spillover at the parallel fiber to stellate cell synapse. J Neurosci 20:44234434. Medline

Cassel JC, Pereira de Vasconcelos A, Loureiro M, Cholvin T, Dalrymple-Alford JC, Vertes RP (2013) The reuniens and rhomboid nuclei: neuroanatomy, electrophysiological characteristics and behavioral implications. Prog Neurobiol 111:34-52. CrossRef Medline

Chowdhury TG, Jimenez JC, Bomar JM, Cruz-Martin A, Cantle JP, PorteraCailliau C (2010) Fate of Cajal-Retzius neurons in the postnatal mouse neocortex. Front Neuroanat 4:10. CrossRef Medline

Cline H, Haas K (2008) The regulation of dendritic arbor development and plasticity by glutamatergic synaptic input: a review of the synaptotrophic hypothesis. J Physiol 586:1509-1517. CrossRef Medline

Cosgrove KE, Maccaferri G (2012) mGlul $\alpha$-dependent recruitment of excitatory GABAergic input to neocortical Cajal-Retzius cells. Neuropharmacology 63:486-493. CrossRef Medline

D’Arcangelo G, Miao GG, Chen SC, Soares HD, Morgan JI, Curran T (1995) A protein related to extracellular matrix proteins deleted in the mouse mutant reeler. Nature 374:719-723. CrossRef Medline

De Marco García NV, Karayannis T, Fishell G (2011) Neuronal activity is required for the development of specific cortical interneuron subtypes. Nature 472:351-355. CrossRef Medline

del Río JA, Martínez A, Fonseca M, Auladell C, Soriano E (1995) Glutamatelike immunoreactivity and fate of Cajal-Retzius cells in the murine cortex as identified with calretinin antibody. Cereb Cortex 5:13-21. CrossRef Medline

Del Río JA, Heimrich B, Borrell V, Förster E, Drakew A, Alcántara S, Nakajima K, Miyata T, Ogawa M, Mikoshiba K, Derer P, Frotscher M, Soriano E (1997) A role for Cajal-Retzius cells and reelin in the development of hippocampal connections. Nature 385:70-74. CrossRef Medline

DiGregorio DA, Nusser Z, Silver RA (2002) Spillover of glutamate onto synaptic AMPA receptors enhances fast transmission at a cerebellar synapse. Neuron 35:521-533. CrossRef Medline

Dingledine R, Borges K, Bowie D, Traynelis SF (1999) The glutamate receptor ion channels. Pharmacol Rev 51:7-61. Medline

Drakew A, Frotscher M, Deller T, Ogawa M, Heimrich B (1998) Developmental distribution of a reeler gene-related antigen in the rat hippocampal formation visualized by CR-50 immunocytochemistry. Neuroscience 82:1079-1086. Medline

Durand GM, Kovalchuk Y, Konnerth A (1996) Long-term potentiation and functional synapse induction in developing hippocampus. Nature 381: 71-75. CrossRef Medline

Elfant D, Pál BZ, Emptage N, Capogna M (2008) Specific inhibitory synapses shift the balance from feedforward to feedback inhibition of hippocampal CA1 pyramidal cells. Eur J Neurosci 27:104-113. CrossRef Medline

Franco SJ, Martinez-Garay I, Gil-Sanz C, Harkins-Perry SR, Müller U (2011) 
Reelin regulates cadherin function via Dab1/Rap1 to control neuronal migration and lamination in the neocortex. Neuron 69:482-497. CrossRef Medline

Frotscher M (1998) Cajal-Retzius cells, Reelin, and the formation of layers. Curr Opin Neurobiol 8:570-575. CrossRef Medline

Fuentealba P, Klausberger T, Karayannis T, Suen WY, Huck J, Tomioka R, Rockland K, Capogna M, Studer M, Morales M, Somogyi P (2010) Expression of COUP-TFII nuclear receptor in restricted GABAergic neuronal populations in the adult rat hippocampus. J Neurosci 30:1595-1609. CrossRef Medline

Gil-Sanz C, Franco SJ, Martinez-Garay I, Espinosa A, Harkins-Perry S, Müller U (2013) Cajal-Retzius cells instruct neuronal migration by coincidence signaling between secreted and contact-dependent guidance cues. Neuron 79:461-477. CrossRef Medline

Glykys J, Dzhala VI, Kuchibhotla KV, Feng G, Kuner T, Augustine G, Bacskai BJ, Staley KJ (2009) Differences in cortical versus subcortical GABAergic signaling: a candidate mechanism of electroclinical uncoupling of neonatal seizures. Neuron 63:657-672. CrossRef Medline

Griveau A, Borello U, Causeret F, Tissir F, Boggetto N, Karaz S, Pierani A (2010) A novel role for Dbx1-derived Cajal-Retzius cells in early regionalization of the cerebral cortical neuroepithelium. PLoS Biol 8:e1000440. CrossRef Medline

Gu X, Liu B, Wu X, Yan Y, Zhang Y, Wei Y, Pleasure SJ, Zhao C (2011) Inducible genetic lineage tracing of cortical hem derived Cajal-Retzius cells reveals novel properties. PLoS One 6:e28653. CrossRef Medline

Hammond VE, So E, Cate HS, Britto JM, Gunnersen JM, Tan SS (2010) Cortical layer development and orientation is modulated by relative contributions of reelin-negative and -positive neurons in mouse chimeras. Cereb Cortex 20:2017-2026. CrossRef Medline

Hanse E, Seth H, Riebe I (2013) AMPA-silent synapses in brain development and pathology. Nat Rev Neurosci 14:839-850. CrossRef Medline

He H, Mahnke AH, Doyle S, Fan N, Wang CC, Hall BJ, Tang YP, Inglis FM, Chen C, Erickson JD (2012) Neurodevelopmental role for VGLUT2 in pyramidal neuron plasticity, dendritic refinement, and in spatial learning. J Neurosci 32:15886-15901. CrossRef Medline

Hevner RF, Neogi T, Englund C, Daza RA, Fink A (2003) Cajal-Retzius cells in the mouse: transcription factors, neurotransmitters, and birthdays suggest a pallial origin. Brain Res Dev Brain Res 141:39-53. CrossRef Medline

Huerta PT, Lisman JE (1993) Heightened synaptic plasticity of hippocampal CA1 neurons during a cholinergically induced rhythmic state. Nature 364:723-725. CrossRef Medline

Imamoto K, Karasawa N, Isomura G, Nagatsu I (1994) Cajal-Retzius neurons identified by GABA immunohistochemistry in layer I of the rat cerebral cortex. Neurosci Res 20:101-105. CrossRef Medline

Ina A, Sugiyama M, Konno J, Yoshida S, Ohmomo H, Nogami H, Shutoh F, Hisano S (2007) Cajal-Retzius cells and subplate neurons differentially express vesicular glutamate transporters 1 and 2 during development of mouse cortex. Eur J Neurosci 26:615-623. CrossRef Medline

Karayannis T, Elfant D, Huerta-Ocampo I, Teki S, Scott RS, Rusakov DA, Jones MV, Capogna M (2010) Slow GABA transient and receptor desensitization shape synaptic responses evoked by hippocampal neurogliaform cells. J Neurosci 30:9898-9909. CrossRef Medline

Kilb W, Luhmann HJ (2001) Spontaneous GABAergic postsynaptic currents in Cajal-Retzius cells in neonatal rat cerebral cortex. Eur J Neurosci 13:1387-1390. CrossRef Medline

Kitamura T, Pignatelli M, Suh J, Kohara K, Yoshiki A, Abe K, Tonegawa S (2014) Island cells control temporal association memory. Science 343: 896-901. CrossRef Medline

Klausberger T, Magill PJ, Márton LF, Roberts JD, Cobden PM, Buzsáki G, Somogyi P (2003) Brain-state- and cell-type-specific firing of hippocampal interneurons in vivo. Nature 421:844-848. CrossRef Medline

Kolodziej A, Schulz S, Guyon A, Wu DF, Pfeiffer M, Odemis V, Höllt V, Stumm R (2008) Tonic activation of CXC chemokine receptor 4 in immature granule cells supports neurogenesis in the adult dentate gyrus. J Neurosci 28:4488-4500. CrossRef Medline

Kwon HB, Sabatini BL (2011) Glutamate induces de novo growth of functional spines in developing cortex. Nature 474:100-104. CrossRef Medline

Langston RF, Ainge JA, Couey JJ, Canto CB, Bjerknes TL, Witter MP, Moser EI, Moser MB (2010) Development of the spatial representation system in the rat. Science 328:1576-1580. CrossRef Medline
Lie DC, Colamarino SA, Song HJ, Désiré L, Mira H, Consiglio A, Lein ES, Jessberger S, Lansford H, Dearie AR, Gage FH (2005) Wnt signalling regulates adult hippocampal neurogenesis. Nature 437:1370-1375. CrossRef Medline

Losonczy A, Zhang L, Shigemoto R, Somogyi P, Nusser Z (2002) Cell type dependence and variability in the short-term plasticity of EPSCs in identified mouse hippocampal interneurones. J Physiol 542:193-210. CrossRef Medline

Louvi A, Yoshida M, Grove EA (2007) The derivatives of the Wnt3a lineage in the central nervous system. J Comp Neurol 504:550-569. CrossRef Medline

Lüscher C, Malenka RC (2012) NMDA receptor-dependent long-term potentiation and long-term depression (LTP/LTD). Cold Spring Harb Perspect Biol 4:a005710. CrossRef Medline

Maccaferri G (2005) Stratum oriens horizontal interneurone diversity and hippocampal network dynamics. J Physiol 562:73-80. CrossRef Medline

Maccaferri G (2011) Modulation of hippocampal stratum lacunosummoleculare microcircuits. J Physiol 589:1885-1891. CrossRef Medline

Maccaferri G, Tóth K, McBain CJ (1998) Target-specific expression of presynaptic mossy fiber plasticity. Science 279:1368-1370. CrossRef Medline

Maccaferri G, Roberts JD, Szucs P, Cottingham CA, Somogyi P (2000) Cell surface domain specific postsynaptic currents evoked by identified GABAergic neurones in rat hippocampus in vitro. J Physiol 524:91-116. CrossRef Medline

MacDermott AB, Mayer ML, Westbrook GL, Smith SJ, Barker JL (1986) NMDA-receptor activation increases cytoplasmic calcium concentration in cultured spinal cord neurones. Nature 321:519-522. CrossRef Medline

Madisen L, Mao T, Koch H, Zhuo JM, Berenyi A, Fujisawa S, Hsu YW, Garcia AJ 3rd, Gu X, Zanella S, Kidney J, Gu H, Mao Y, Hooks BM, Boyden ES, Buzsáki G, Ramirez JM, Jones AR, Svoboda K, Han X, Turner EE, Zeng H (2012) A toolbox of Cre-dependent optogenetic transgenic mice for light-induced activation and silencing. Nat Neurosci 15:793-802. CrossRef Medline

Manent JB, Represa A (2007) Neurotransmitters and brain maturation: early paracrine actions of GABA and glutamate modulate neuronal migration. Neuroscientist 13:268-279. CrossRef Medline

Manent JB, Demarque M, Jorquera I, Pellegrino C, Ben-Ari Y, Aniksztejn L, Represa A (2005) A noncanonical release of GABA and glutamate modulates neuronal migration. J Neurosci 25:4755-4765. CrossRef Medline

Manent JB, Jorquera I, Ben-Ari Y, Aniksztejn L, Represa A (2006) Glutamate acting on AMPA but not NMDA receptors modulates the migration of hippocampal interneurons. J Neurosci 26:5901-5909. CrossRef Medline

Marchionni I, Takács VT, Nunzi MG, Mugnaini E, Miller RJ, Maccaferri G (2010) Distinctive properties of CXC chemokine receptor 4-expressing Cajal-Retzius cells versus GABAergic interneurons of the postnatal hippocampus. J Physiol 588:2859-2878. CrossRef Medline

Marchionni I, Beaumont M, Maccaferri G (2012) The chemokine CXCL12 and the HIV-1 envelope protein gp120 regulate spontaneous activity of Cajal-Retzius cells in opposite directions. J Physiol 590:3185-3202. CrossRef Medline

Marín-Padilla M (1998) Cajal-Retzius cells and the development of the neocortex. Trends Neurosci 21:64-71. CrossRef Medline

Mayer ML, Westbrook GL, Guthrie PB (1984) Voltage-dependent block by $\mathrm{Mg} 2+$ of NMDA responses in spinal cord neurones. Nature 309:261-263. CrossRef Medline

Meijering E, Jacob M, Sarria JC, Steiner P, Hirling H, Unser M (2004) Design and validation of a tool for neurite tracing and analysis in fluorescence microscopy images. Cytometry A 58:167-176. CrossRef Medline

Miles R, Wong RK (1987) Inhibitory control of local excitatory circuits in the guinea-pig hippocampus. J Physiol 388:611-629. Medline

Mori M, Abegg MH, Gähwiler BH, Gerber U (2004) A frequencydependent switch from inhibition to excitation in a hippocampal unitary circuit. Nature 431:453-456. CrossRef Medline

Nowak L, Bregestovski P, Ascher P, Herbet A, Prochiantz A (1984) Magnesium gates glutamate-activated channels in mouse central neurones. Nature 307:462-465. CrossRef Medline

Ogawa M, Miyata T, Nakajima K, Yagyu K, Seike M, Ikenaka K, Yamamoto H, Mikoshiba K (1995) The reeler gene-associated antigen on CajalRetzius neurons is a crucial molecule for laminar organization of cortical neurons. Neuron 14:899-912. CrossRef Medline

Pesold C, Impagnatiello F, Pisu MG, Uzunov DP, Costa E, Guidotti A, Car- 
uncho HJ (1998) Reelin is preferentially expressed in neurons synthesizing gamma-aminobutyric acid in cortex and hippocampus of adult rats. Proc Natl Acad Sci U S A 95:3221-3226. CrossRef Medline

Petreanu L, Mao T, Sternson SM, Svoboda K (2009) The subcellular organization of neocortical excitatory connections. Nature 457:1142-1145. CrossRef Medline

Portera-Cailliau C, Pan DT, Yuste R (2003) Activity-regulated dynamic behavior of early dendritic protrusions: evidence for different types of dendritic filopodia. J Neurosci 23:7129-7142. Medline

Quattrocolo G, Maccaferri G (2013) Novel GABAergic circuits mediating excitation/inhibition of Cajal-Retzius cells in the developing hippocampus. J Neurosci 33:5486-5498. CrossRef Medline

Rajan I, Cline HT (1998) Glutamate receptor activity is required for normal development of tectal cell dendrites in vivo. J Neurosci 18:7836-7846. Medline

Reyes A, Lujan R, Rozov A, Burnashev N, Somogyi P, Sakmann B (1998) Target-cell-specific facilitation and depression in neocortical circuits. Nat Neurosci 1:279-285. CrossRef Medline

Rivera C, Voipio J, Payne JA, Ruusuvuori E, Lahtinen H, Lamsa K, Pirvola U, Saarma M, Kaila K (1999) The K+/Cl- co-transporter KCC2 renders GABA hyperpolarizing during neuronal maturation. Nature 397:251255. CrossRef Medline

Shao LR, Dudek FE (2009) Both synaptic and intrinsic mechanisms underlie the different properties of population bursts in the hippocampal CA3 area of immature versus adult rats. J Physiol 587:5907-5923. CrossRef Medline

Shepherd AJ, Loo L, Gupte RP, Mickle AD, Mohapatra DP (2012) Distinct modifications in Kv2.1 channel via chemokine receptor CXCR4 regulate neuronal survival-death dynamics. J Neurosci 32:17725-17739. CrossRef Medline

Shepherd GM, Koch C (1990) Introduction to synaptic circuits. In: The synaptic organization of the brain (Shepherd GM, ed), pp 3-31. New York: Oxford UP.

Soda T, Nakashima R, Watanabe D, Nakajima K, Pastan I, Nakanishi S (2003) Segregation and coactivation of developing neocortical layer 1 neurons. J Neurosci 23:6272-6279. Medline

Soriano E, Del Río JA (2005) The cells of cajal-retzius: still a mystery one century after. Neuron 46:389-394. CrossRef Medline

Spigelman I, Zhang L, Carlen PL (1992) Patch-clamp study of postnatal development of CA1 neurons in rat hippocampal slices: membrane excitability and $\mathrm{K}^{+}$currents. J Neurophysiol 67:55-69. Medline

Steward O, Scoville SA (1976) Cells of origin of entorhinal cortical afferents to the hippocampus and fascia dentata of the rat. J Comp Neurol 169:347370. CrossRef Medline

Stumm RK, Rummel J, Junker V, Culmsee C, Pfeiffer M, Krieglstein J, Höllt V, Schulz S (2002) A dual role for the SDF-1/CXCR4 chemokine receptor system in adult brain: isoform-selective regulation of SDF-1 expression modu- lates CXCR4-dependent neuronal plasticity and cerebral leukocyte recruitment after focal ischemia. J Neurosci 22:5865-5878. Medline

Stumm RK, Zhou C, Ara T, Lazarini F, Dubois-Dalcq M, Nagasawa T, Höllt V, Schulz S (2003) CXCR4 regulates interneuron migration in the developing neocortex. J Neurosci 23:5123-5130. Medline

Supèr H, Martínez A, Del Río JA, Soriano E (1998) Involvement of distinct pioneer neurons in the formation of layer-specific connections in the hippocampus. J Neurosci 18:4616-4626. Medline

Szapiro G, Barbour B (2007) Multiple climbing fibers signal to molecular layer interneurons exclusively via glutamate spillover. Nat Neurosci 10: 735-742. CrossRef Medline

Tissir F, Goffinet AM (2003) Reelin and brain development. Nat Rev Neurosci 4:496-505. CrossRef Medline

Tissir F, Wang CE, Goffinet AM (2004) Expression of the chemokine receptor Cxcr4 mRNA during mouse brain development. Brain Res Dev Brain Res 149:63-71. Medline

Torborg CL, Nakashiba T, Tonegawa S, McBain CJ (2010) Control of CA3 output by feedforward inhibition despite developmental changes in the excitation-inhibition balance. J Neurosci 30:15628-15637. CrossRef Medline

Varga C, Golshani P, Soltesz I (2012) Frequency-invariant temporal ordering of interneuronal discharges during hippocampal oscillations in awake mice. Proc Natl Acad Sci U S A 109:E2726-E2734. CrossRef Medline

Vaughn JE, Barber RP, Sims TJ (1988) Dendritic development and preferential growth into synaptogenic fields: a quantitative study of Golgiimpregnated spinal motor neurons. Synapse 2:69-78. CrossRef Medline

Vida I, Halasy K, Szinyei C, Somogyi P, Buhl EH (1998) Unitary IPSPs evoked by interneurons at the stratum radiatum-stratum lacunosummoleculare border in the CA1 area of the rat hippocampus in vitro. J Physiol 506:755-773. CrossRef Medline

Williams SC, Deisseroth K (2013) Optogenetics. Proc Natl Acad Sci U S A 110:16287. CrossRef Medline

Wills TJ, Cacucci F, Burgess N, O'Keefe J (2010) Development of the hippocampal cognitive map in preweanling rats. Science 328:1573-1576. CrossRef Medline

Yamazaki H, Sekiguchi M, Takamatsu M, Tanabe Y, Nakanishi S (2004) Distinct ontogenic and regional expressions of newly identified CajalRetzius cell-specific genes during neocorticogenesis. Proc Natl Acad Sci U S A 101:14509-14514. CrossRef Medline

Yoshida M, Assimacopoulos S, Jones KR, Grove EA (2006) Massive loss of Cajal-Retzius cells does not disrupt neocortical layer order. Development 133:537-545. CrossRef Medline

Zsiros V, Maccaferri G (2005) Electrical coupling between interneurons with different excitable properties in the stratum lacunosum-moleculare of the juvenile CA1 rat hippocampus. J Neurosci 25:8686-8695. CrossRef Medline 